\title{
First Record of a living Platycopida (Crustacea, Ostracoda) from Antarctic waters and a Discussion on Cytherella serratula (Brady, 1880)*
}

\author{
SIMONE N. BRANDÃO \\ Biozentrum Grindel und Zoologisches Museum, Universität Hamburg, Martin-Luther-King Platz 3, 20146 Hamburg, Germany. \\ Email: snbrandao@terra.com.br
}

*In: Martínez Arbizu, P. \& Brix, S. (Eds) (2008) Bringing Light into Deep-sea Biodiversity. Zootaxa, 1866, 1-574.

\begin{abstract}
Previous records of Platycopida (Ostracoda) from the Antarctic region of the Southern Ocean include only a few fossil species from the Late Cretaceous to the Palaeocene: Cytherelloidea megaspirocostata Majoran \& Widmark, 1998, [sic] Cytherella serratula (Brady, 1880), plus seven species left in open nomenclature. The present study documents the first record of a living platycopid from the Antarctic region and describes Cytherella rwhatleyi sp. nov. as new. Comparison among specimens collected at stations $60^{\circ}$ longitude and $10^{\circ}$ of latitude apart from each other show that very little intraspecific variation in outline and ornamentation of the valves, as well as on the hemipenis is presented by this new species. Otherwise, clear differences on valve and hemipenis are observed between different species (herein, Jellinek \& Swanson 2003). Review of the literature indicates that several species (with great differences in valve outline and ornamentation) have been erroneously assigned to Cytherella serratula (Brady, 1880) demonstrating that this so-called cosmopolitan taxon is in truth most probably restricted to bathyal depths of the Northwestern Atlantic. Finally, the abundances of Cytherella rwhatleyi sp. nov. in the samples studied herein (considering $\mathrm{O}_{2}$ concentration measurements) contradict the proposed relationship between Platycopida and $\mathrm{O}_{2}$ concentration in water masses (Whatley et al. 2003).
\end{abstract}

Key words: Ostracoda; Platycopida; new species; Southern Ocean; continental slope; deep-sea

\section{Introduction}

Although previous studies on Ostracoda record more than 200 species from the Antarctic region of the Southern Ocean sensu Hedgpeth, (1969) and De Broyer et al. (2004) (=southern to the Polar Frontal region), none cite living Platycopida (Hartmann 1997). This fact is surprising since platycopids have been present in Antarctic waters from the Cretaceous to the Oligocene (Majoran et al. 1997, Dingle \& Majoran 2001, Majoran \& Dingle 2002, Fauth et al. 2003) (Fig. 1 herein), and still occur nowadays in the Subantarctic and Subtropical regions of the Southern Ocean (Fig. 1) (Bergue et al. 2007, Chapman 1919, Dingle et al. 1990, Jellinek \& Swanson 2003, Majoran et al. 1997, Majoran \& Dingle 2001a, 2001b, Whatley \& Cusminsky 2002, Whatley et al. 1996, 1997, 1998).

Seven species recorded from the Antarctic Region were left in open nomenclature, with only two species being named so far: Cytherelloidea megaspirocostata Majoran \& Widmark, 1998 and [sic] Cytherella serratula (Brady, 1880) (see below discussion on the misidentifications on this species). Cytherelloidea megaspirocostata, Cytherella sp. 1, and Cytherella sp. 2 occur in the middle to late Campanian (Upper Creataceous) of James Ross Island, Antarctic Peninsula (Fauth et al. 2003); and Cytherella sp. and Cytherelloidea sp. were 
recorded from the Maastrichtian (Upper Cretaceous) from Maud Rise and Northeastern Georgia Rise respectively (Majoran et al. 1997). In the Cenozoic, few unidentified species of the genus Cytherella were reported from the Palaeocene and Eocene of the Maud Rise (Majoran \& Dingle 2002) and from the Oligocene of the Victoria Land Basin (Dingle \& Majoran 2001). In addition, a number of fossil and living platycopids have been collected from the deep-sea southern Atlantic and Indic / Pacific Oceans, with special reference to the highly diverse fauna of the Tasman Sea, and the Challenger and Campbell Plateaus: Cytherella hiatus Swanson et al. 2005, C. intonsa Swanson et al. 2005, C. corpusculum Swanson et al. 2005, C. plusminusve Swanson et al. 2005, C. permutata Swanson et al. 2005, Grammcythella dyspnoea Swanson et al. 2005, and Inversacytherella tanantia Swanson et al. 200 (Jellinek \& Swanson 2003, Swanson et al. 2005).

The theory on the relationship between the $\mathrm{O}_{2}$ concentration in the water mass and the numerical abundance of filter feeding ostracods, including the genus Cytherella, states that the filter feeding strategy would cause a higher ecological success of during kenoxic/anoxic events, because the higher water circulation inside the carapace (Whatley 1991). Furthermore, eggs brooded by the female inside of the carapace, would also profit from the higher ventilation and would consequently have higher survival chances than eggs lain in the environment (Jarvis et al. 1988). This hypothesis is tested in the present study.

In the present work, 207 live specimens of a recent platycopid species are studied. This material was collected during two cruises of the R. V. Polarstern from the continental slope off Antarctica (Weddell and Scotia Seas). These specimens belong to a new species, Cytherella rwhatleyi sp. nov., described and illustrated herein. The large number of living specimens made an evaluation on the intraspecific morphological variability in a deep-sea cytherellid possible. This evaluation is one of the key objectives of the taxonomy and has important implications for studies of biodiversity, genetic, paleoenvironmental, and geochemistry.

Furthermore, I studied the type material of Cytherella serratula (Brady, 1880) and discuss its previous records, which proposed geographical distribution include from the North and South Atlantic, the IndoPacific and the Southern oceans. Based on published illustrations, the morphologies of the different specimens are compared.

\section{Material and Methods}

Two cruises of the German R. V. Polarstern (ANT XV/3, in the summer of 1998 - EASIZ Project; ANT XXII/3 - ANDEEP Project, in the summer and beginning of the spring of 2005) in the Scotia and Weddell Seas, Southern Ocean, provided 207 live platycopid specimens, among them many gravid females. These specimens were collected in four different stations (Tab. 1, Fig. 1) from 938 to 2069 meters depth using the gears epibenthic sledge (EBS), Agassiz trawl (AGT) and giant box corer (GKG). For details on EASIZ II and ANDEEP III expeditions see Arntz \& Gutt (1999) and Fahrbach (2006), respectively.

EASIZ II specimens (\#89 and \#107) were fixed in formalin 4\% and transferred to ethanol $96 \%$ after sorting. ANDEEP III specimens were fixed either in pre-cooled $\left(-40^{\circ} \mathrm{C}\right) 96 \%$ ethanol (EBS samples), or in formalin 4\% (AGT sample \# 57-2, and GKG sample \# 153-4,), or in 3\% glutardialdehyde in $0.05 \%$ phosphate buffer (AGT sample 153-8).

For the study of the "soft parts" in the scanning electron microscope, ten specimens (SNB 0692-0694, 0697-0701) of the sample \#153-8 were washed 3 three times for 15 minutes in 0.05\% phosphate buffer, and subsequently dehydrated in graded series of ethanol from $30 \%$ to $100 \%$ in $10 \%$ steps and at least 15 minutes in each step. The animals were critical point dried in a Balzers CPT Dryer with $\mathrm{CO}_{2}$. One of the valves of each specimen was dissected in the dried stage with needles. After a shading procedure with carbon or gold in an evaporation unit PD170AZ from Leybold-Heraeus the single shells and the critical point dried specimens were observed and photographed in a LEO 1525 SEM.

All the specimens studied herein were deposited in the Crustacea collection of the Zoologisches Institut und Museum, University of Hamburg (Germany), under the abbreviation ZMH K. The appendage and 
podomere nomenclature mostly follow Tsukagoshi et al. (2006, Figs. 7-9). The chaetotaxy descriptions are based on Schornikov and Keyser (2004), with one modification: c=comb setae (of mandible and maxilla I), l=long (for setae), m=medium-sized (for setae). Maps were made on Ocean Data View Program (Schlitzer 2007).

Abbreviations. A, adult(s); (A-1), (A-2), (A-3), juvenile stages; AGT, Agassiz trawl; AI, antenna I; AII, antenna II; ApV, ApVI, ApVII, fifth to seventh appendages; BM, The Natural History Museum, London (England); GKG, giant boxcorer; dv, dorsal view; EBS, epibenthicsledge; ev, external view; H, height; HP, hemipenis; iv, internal view; L, length; LV, left valve(s); Md, mandible; m, metres; mm, millimetres; MxI, maxilla I; RLV, closed right and left valves without soft parts; RV, right valve(s); SNB, specimen number as catalogued by the present author; SP, soft parts; sp(p)., species (plural); V, valve(s); ZMH, Zoologisches Institut und Museum, University of Hamburg (Germany); \#, station; , approximately.

\section{Taxonomy}

Class Ostracoda Latreille, 1802, Subclass Podocopa Müller, 1894, Order Platycopida Sars, 1866, Suborder Platycopina Sars, 1866, Superfamily Cytherelloidea Sars, 1866

Family Cytherellidae Sars, 1866

Genus Cytherella Jones, 1849

Type-species. Cytherella ovata (Roemer, 1840)

\section{Cytherella rwhatleyi sp. nov.}

(Figs. 1-8, Tabs. 1, 2, 4)

Etymology. In honour of Dr. Robin Whatley, who published many studies on fossil and recent ostracods.

Material. 207 live specimens (64 adult males, 124 adult females, 15 (A-1), 1 (A-?2) + 3 specimens), 1 female RLV, 1 female RV.

Holotype - 1 adult male (SNB 0131), EASIZ II, \# 89, ZMH K-41280.

Paratypes -15 adult males, 10 adult females, 3 (A-1), (SNB 0018, 0132-4), 1 adult female RV, EASIZ II, \# 89, ZMH K-41282; 1 adult male (SNB 0135), 4 adult females (SNB 0136), EASIZ II, \# 107, ZMH K41283; 1 adult male (SNB 0159), 1 adult female (SNB 0158), ANDEEP III, \# 57 - 2, ZMH K-41284; 1 adult male (SNB 0169), 1 adult female (SNB 0168), +2 adult and 1 juvenile specimens, ANDEEP III, \# $153-4$, ZMH K-41285; 15 adult males (SNB 0170), 14 adult females, 8 (A-1) (SNB 0688, 0690-1), 1 (A-?2) (SNB 0689), ANDEEP III, \# 153 - 7 - E, ZMH K-41286; 28 adult males, 81 adult females, 4 (A-1), 1 female RLV, ANDEEP III, \# 153 - 7 - S, ZMH K-41287; 2 adult males (SNB 0693-4), 13 adult females (SNB 0692, 06970701), ANDEEP III, \# 153 - 8, ZMH K-41288.

Distribution. Northeastern Weddell Sea and Southwestern Scotia Sea, Antarctic Region of the Southern Ocean, 938 and $2069 \mathrm{~m}$.

V Measurements (Fig. 2). Holotype-RV L 1.03mm, H 0.58mm, LV L 1.02mm, H 0.53mm; Paratypesadult male RV L 1.01-1.08mm, H 0.57-0.61mm; adult females RV L 1.00-1.11mm, H 0.58-0.65mm; (A-1) RV L $0.85-0.90 \mathrm{~mm}$, H $0.54-0.58 \mathrm{~mm}$; (A-?2) RV 0.72mm, H $0.42 \mathrm{~mm}$.

Diagnosis. In lateral view, RV and LV oval - sub-rectangular; very wide rim present on entire valve margin in males, but only on anterodorsal to ventral areas of valves in females; anterior margin more broadly rounded than posterior; pronounced selvage present, with shorter and longer radial setae. Lateral surface with medium-sized, shallow, punctae present on almost entire valve surface except by the adductor muscle scar and ventral - anteroventral areas. Genital lobe proximally subcircular, with "beak-shaped" distal process, which is convex anteriorly and concave posteriorly. HP very elongated and relatively thin, with "heart-shaped" proximal lobe, and subtriangular distal lobe. 


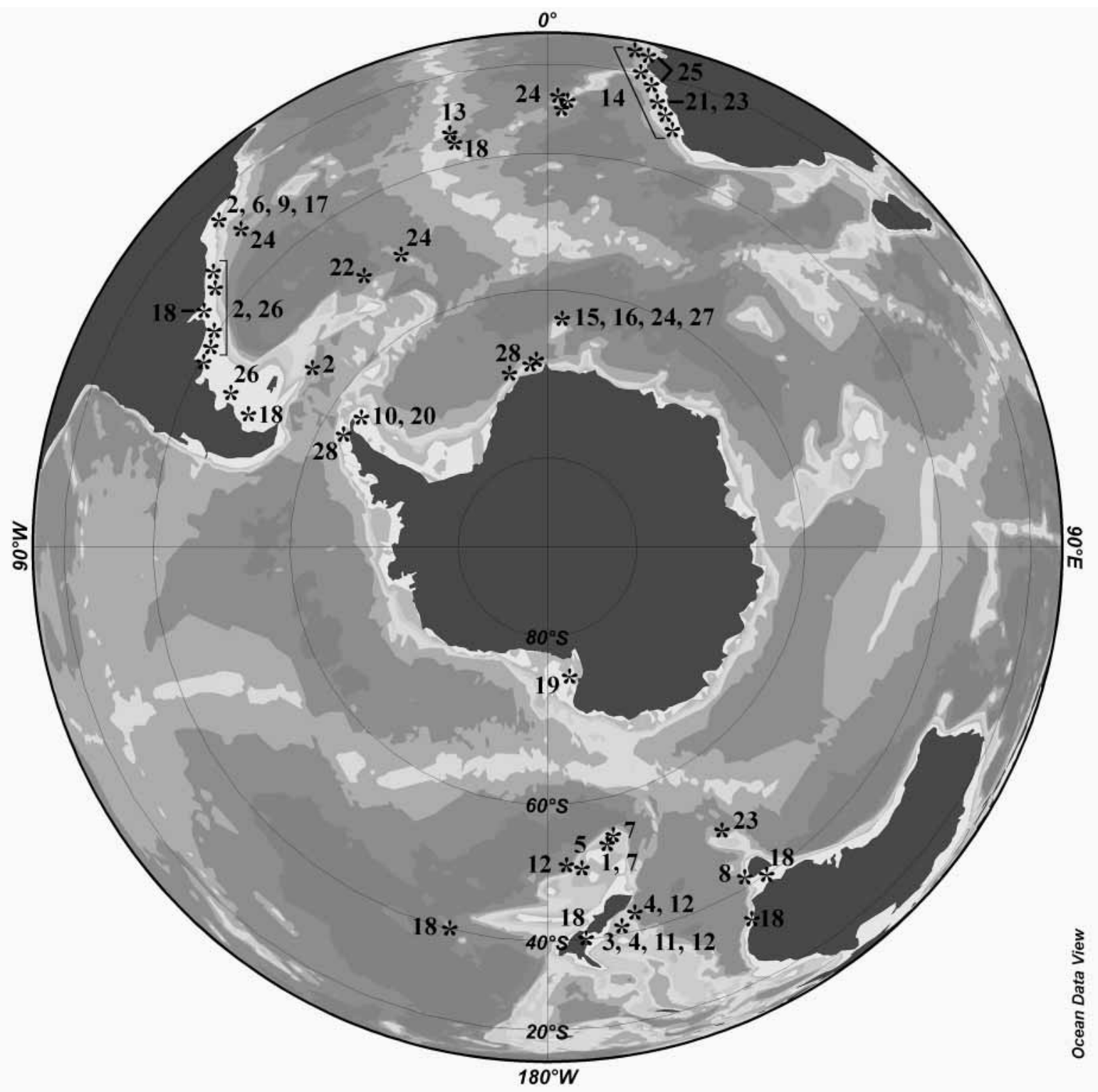

FIGURE 1. Previous records of Platycopida in the Southern Ocean and vicinities.

Fossil records included only for the Antarctic region, for other regions only recent and subfossil records represented. 1-Cytherella corpusculum Swanson et al. 2005, Recent; 2-Cytherella hermargentina Whatley et al. 1998, subfossil; 3-Cytherella hiatus Swanson et al. 2005, Recent; 4-Cytherella intonsa Swanson et al. 2005, Recent; 5-Cytherella permutata Swanson et al. 2005, Recent; 6-Cytherella pleistocenica Bergue et al. 2007, Late Quaternary; 7-Cytherella plusminusve Swanson et al. 2005, Recent; 8-Cytherella punctata Brady, 1865, Recent???; 9-Cytherella santosensis Bergue et al. 2007, Late Quaternary; 10—Cytherelloidea megaspirocostata Majoran \& Widmark, 1998, Upper Cretaceous (from Fauth et al. 2003); 11-Grammcythella dyspnoea Swanson et al. 2005, Recent; 12-Inversacythella tanantia Swanson et al. 2005, Recent; 13-17-Cytherella spp. (as C. serratula (Brady, 1880)), Paleocene to Recent; 18-Cytherella spp.-as C. cavernosa, C. cingulata, C. polita, C. punctata, and C. pulchra from the first report on the Challenger expedition ostracods (Brady 1880), Recent; 19-26-Cytherella spp., Upper Cretaceous to Recent; 27-Cytherelloidea sp., Late Cretaceous to Oligocene; 28-Cytherella rwhatleyi sp. nov., Recent.

Bibliographical Sources: 1, 3-5, 7, 11, 12-from Jellinek \& Swanson (2003) and Swanson et al. (2005); 2-from Bergue et al. (2007), Whatley \& Cusminsky (2002), and Whatley et al. (1996, 1997,1998); 6, 9, 17—from Bergue et al. (2007); 8-from Chapman (1919); 10_Cytherelloidea megaspirocostata Majoran \& Widmark, 1998, Upper Cretaceous (from Fauth et al. 2003); 13-from Brady 1880; 14-Quaternary, from Dingle et al. (1990); 15-Eocene, from Majoran \& Dingle (2002); 16-Palaeocene to Oligocene, Majoran \& Dingle (2002); 18 - Recent, Brady, 1880; 19—Oligocene, from Dingle \& Majoran (2001); 20-Upper Cretaceous, from Fauth et al. (2003); 21—Quaternary, from Dingle et al. (1990); 22—Eocene, from Majoran \& Dingle (2001b); 23—subfossil, from Mazzini (2005); 24-Late Cretaceous, from Majoran et al. (1997); 25—Peypouquet \& Benson (1980); 26—subfossil, from Whatley et al. (1997, 1998); 27—Eocene to Oligocene, from Majoran \& Dingle (2002); 28—Recent, herein. 


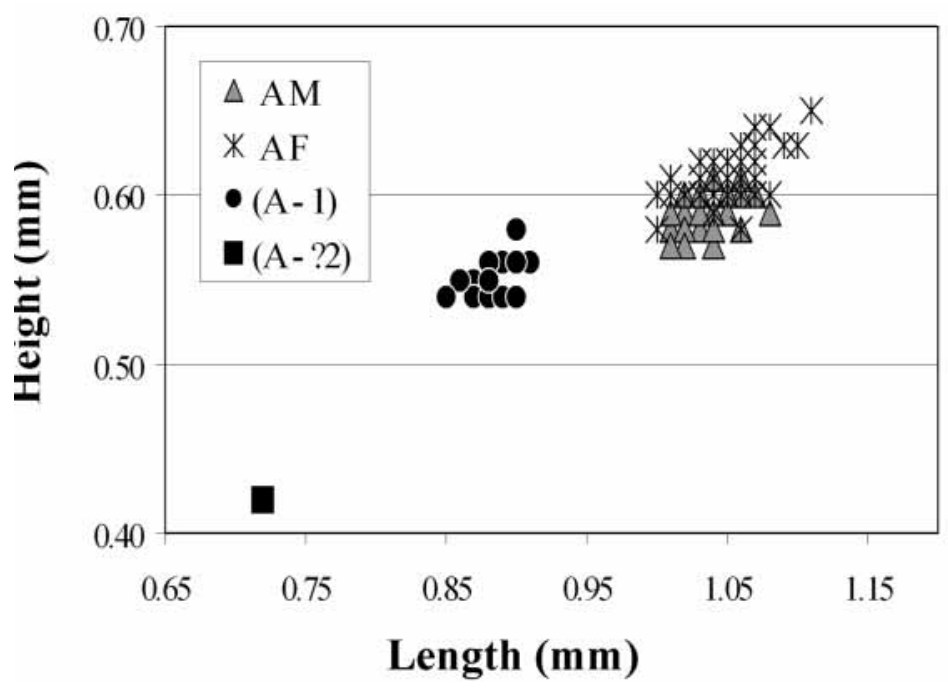

FIGURE 2. Length: height scatter plot of adult and juvenile valves of Cytherella rwhatleyi sp. nov.

TABLE 1. Stations with samples containing Cytherella rwhatleyi sp. nov.

\begin{tabular}{|c|c|c|c|c|c|c|c|c|c|c|c|}
\hline \multirow[t]{2}{*}{ Station } & \multirow{2}{*}{$\begin{array}{l}\text { Polarstern } \\
\text { Expedition }\end{array}$} & \multirow[t]{2}{*}{ Project } & \multirow[t]{2}{*}{ Date } & \multirow[t]{2}{*}{ Time } & \multicolumn{2}{|c|}{ Latitude } & \multicolumn{2}{|c|}{ Longitude } & \multirow{2}{*}{$\begin{array}{c}\text { Depth } \\
\text { (m) }\end{array}$} & \multirow[t]{2}{*}{ Gear } & \multirow[t]{2}{*}{ Sediment } \\
\hline & & & & & $\mathrm{S}$ begin & $S$ end & W begin & $W$ end & & & \\
\hline 89 & PS48/ANTXV-3 & EASIZ II & 04.02 .98 & $10: 24$ & $73^{\circ} 27.26^{\prime}$ & $73^{\circ} 27.27^{\prime}$ & $22^{\circ} 45.67^{\prime}$ & $22^{\circ} 46.52^{\prime}$ & 1645 & EBS & NI \\
\hline 107 & PS48/ANTXV-3 & EASIZ II & 06.02 .98 & $8: 24$ & $73^{\circ} 34.77^{\prime}$ & $73^{\circ} 34.92^{\prime}$ & $22^{\circ} 38.29^{\prime}$ & $22^{\circ} 38.89^{\prime}$ & 938 & EBS & fine gravel \\
\hline $57-2$ & PS67/ANTXXII-3 & ANDEEP III & 10.02 .05 & $18: 44$ & $69^{\circ} 24.15^{\prime}$ & $69^{\circ} 24.63^{\prime}$ & $5^{\circ} 18.40^{\prime}$ & $5^{\circ} 19,70^{\prime}$ & 1812 & AGT & NI \\
\hline $153-4$ & PS67/ANTXXII-3 & ANDEEP III & 29.03 .05 & 08:52 & $63^{\circ} 19.35^{\prime}$ & - & $64^{\circ} 36.79^{\prime}$ & - & 2079 & GKG & $\begin{array}{l}72 \% \text { silt, } 13 \% \\
\text { sand, } 15 \% \text { clay }\end{array}$ \\
\hline $153-7$ & PS67/ANTXXII-3 & ANDEEP III & 29.03 .05 & $13: 33$ & $63^{\circ} 19.83^{\prime}$ & $63^{\circ} 19.19^{\prime}$ & $64^{\circ} 36.44^{\prime}$ & $64^{\circ} 37.52^{\prime}$ & 2011 & EBS & $\begin{array}{l}72 \% \text { silt, } 13 \% \\
\text { sand, } 15 \% \text { clay }\end{array}$ \\
\hline $153-8$ & PS67/ANTXXII-3 & ANDEEP III & 29.03 .05 & $16: 37$ & $63^{\circ} 19.53^{\prime}$ & $63^{\circ} 19.06^{\prime}$ & $64^{\circ} 36.79^{\prime}$ & $64^{\circ} 37.23^{\prime}$ & 2069 & AGT & $\begin{array}{l}72 \% \text { silt, } 13 \% \\
\text { sand, } 15 \% \text { clay }\end{array}$ \\
\hline
\end{tabular}

NI—no information available. For other abbreviations see Material and Methods.

Description. In Lateral view, RV and LV oval to sub-rectangular; very wide rim present on entire valve margin in males, but only on anterodorsal to ventral areas of valves in females (because of the posterior inflated form due to the brood chamber); dorsal margin fairly straight; ventral margin slightly concave in females and concave in males; anterior margin more broadly rounded than posterior. Pronounced selvage present, with shorter and longer radial setae. Lateral surface punctate, punctae medium-sized, shallow, and present on almost entire valve surface except by the adductor muscle scar and ventral-anteroventral areas; one to three slight, small tubercles (related to muscle insertions on interior surface of valves) present on mid-dorsal area of lateral surface. Maximum height anterior to midlength; in males greatest length at mid-height, and greatest width at mid length; in females, greatest length inferior to mid-length, and greatest width posterior to mid-length. Few, very long setae arising from carapace posterior; shorter, simple or feathered setae arising from simple, "bean-shaped" to circular, lateral pore canals. RV slightly larger and overlaping LV mid-dorsally. In dorsal view, males with sinuous outline (due to wide rim), females with subtriangular outline (due to brood chamber). Adductor muscle scars composed by 2 vertical rows, each with six scars, plus one dorsal scar. Sexual dimorphism pronounced; females higher in relation to length and wider than males; female with inflated posterior (=brood chamber) without limen (ridge or elevation forming the anterior boundary of brood cham- 
ber). Females brooded from 0 to 6 eggs, with a maximum of 3 eggs per valve (Fig. 6, Tab. 2), in average 3.6 eggs / female; exact position of single eggs in brood chamber also varied (ventral, medial or dorsal).

TABLE 2. Number of eggs brooded by single females of Cytherella rwhatleyi sp. nov. in the different stations.

\begin{tabular}{cccccc}
\hline LV & RV & $\# 89$ & $\# 107$ & $\# 153$ & Total \\
\hline 0 & 0 & 0 & 0 & 10 & 10 \\
0 & 1 & 0 & 0 & 3 & 3 \\
0 & 2 & 0 & 0 & 2 & 2 \\
1 & 0 & 2 & 1 & 2 & 5 \\
1 & 1 & 0 & 0 & 6 & 6 \\
1 & 2 & 0 & 5 & 3 \\
1 & 3 & 0 & 0 & 1 \\
2 & 0 & 0 & 0 & 1 & 3 \\
2 & 1 & 0 & 1 & 12 & 13 \\
2 & 2 & 1 & 0 & 13 & 15 \\
3 & 3 & 2 & 0 & 2 & 2 \\
3 & 1 & 0 & 0 & 17 & 9 \\
& 2 & 0 & 0 & 9 & 9 \\
\end{tabular}

For abbreviations see Material and Methods.

AI robust, with 7 podomeres, podomere III subtriangular; chaetotaxy 1(0/.3.1.1), 2(.1r/.3), 3(.1/1r), 4(.3/ $0: 1,1,1), 5(0 / 0: 2,1), 6(.1 \mathrm{~m}, 1 \mathrm{r} / 0: 21), 7(0 / 0: 3 \mathrm{~m}, 0-1 \mathrm{r} .1 \mathrm{~m})$. Base of AII with barbed dorsal margin; endopodite podomere I with 6 (3 ventral plus 3 distal) modified setae, which lack any kind of pore indicative of chemical reception; chaetotaxy-Coxa (.1.1/0), Basis (0/.2-3), Exopodite I (0/0: 4-5), Exopodite II (.0-1./0:7), Endopodite I (0/3r.:6-7.5-6,3r), Endopodite II+III (.1-2.1-2/.1), Endopodite IV (0/.1.:3). Coxa of Md with 2 endites finely denticulate distally; approximatelly $60 \mathrm{comb}$ setae; chaetotaxy_Exopodite (4), Endopodite I (0/0:3). Endites of MxI with numerous setae and barbae; MxI chaetotaxy-Coxa (.1/0), Base (0/.11.4, 50c), Exopodite ( 30), Endopodite I (.1-2/.1.1.1.1.), Endopodite II (0/0:3-4). ApV strongly sexually dimorphic, endopodite well developed, hook-shaped in male and reduced in female; chaetotaxy of ApV of male-Endite (7-8,0-1r), Exopodite ( 20), Endopodite I (0/.2.1-2), Endopodite II (0/.1-2.1-2.2-3), Endopodite III (0/.1:1,12). ApVI also strongly sexually dimorphic, endopodite well developed, hook-shaped in male and absent in female; chaetotaxy of ApVI of male-Exopodite ( 13), Endopodite I (0/.1.1.), Endopodite II (.11/.1.1.1), Endopodite III (0/.1:3); chaetotaxy of ApVI of female-Exopodite ( 7). Fu a pair of lamella bearing 9 to 11 feathered setae plus 1 reduced seta. HP very elongated and relatively thin, with "heart-shaped" proximal lobe, and subtriangular distal lobe. Genital lobe proximally subcircular, with "beak-shaped" distal process, which is convex anteriorly and concave posteriorly. Trunk with 11 segments, males bearing several short setae and females bearing long setae. HP inserted in segments V to VII (segment I most posterior, following Tsukagoshi et al. 2006), genital lobe inserted in segments V to VIII.

FIGURE 3. Adult valves of Cytherella rwhatleyi sp. nov. from the different stations in the Scotia and Weddell Seas.

A, C, E, G, I, K, RV ev; B, D, F, H, J, L, LV ev; M, RV and LV dv; N, RLV dv; O, RLV vv; P, adductor muscle scars.

A, B, paratype adult female (ZMH K-41282, SNB 0018); C, D, paratype adult female (ZMH K-41283, SNB 0136); E, F, paratype adult female (ZMH K-41285, SNB 0168); G, H, M, holotype adult male (ZMH K-41280, SNB 0131); I, J, paratype adult male (ZMH K-41283, SNB 0135); K, L, paratype adult male (ZMH K-41286, SNB 0170); N, paratype adult female (ZMH K-41288, SNB 0696); O, paratype adult female (ZMH K-41288, SNB 0695). Scale bars: A-O, 500 $\mu \mathrm{m} ; \mathbf{P}, 20 \mu \mathrm{m}$. 


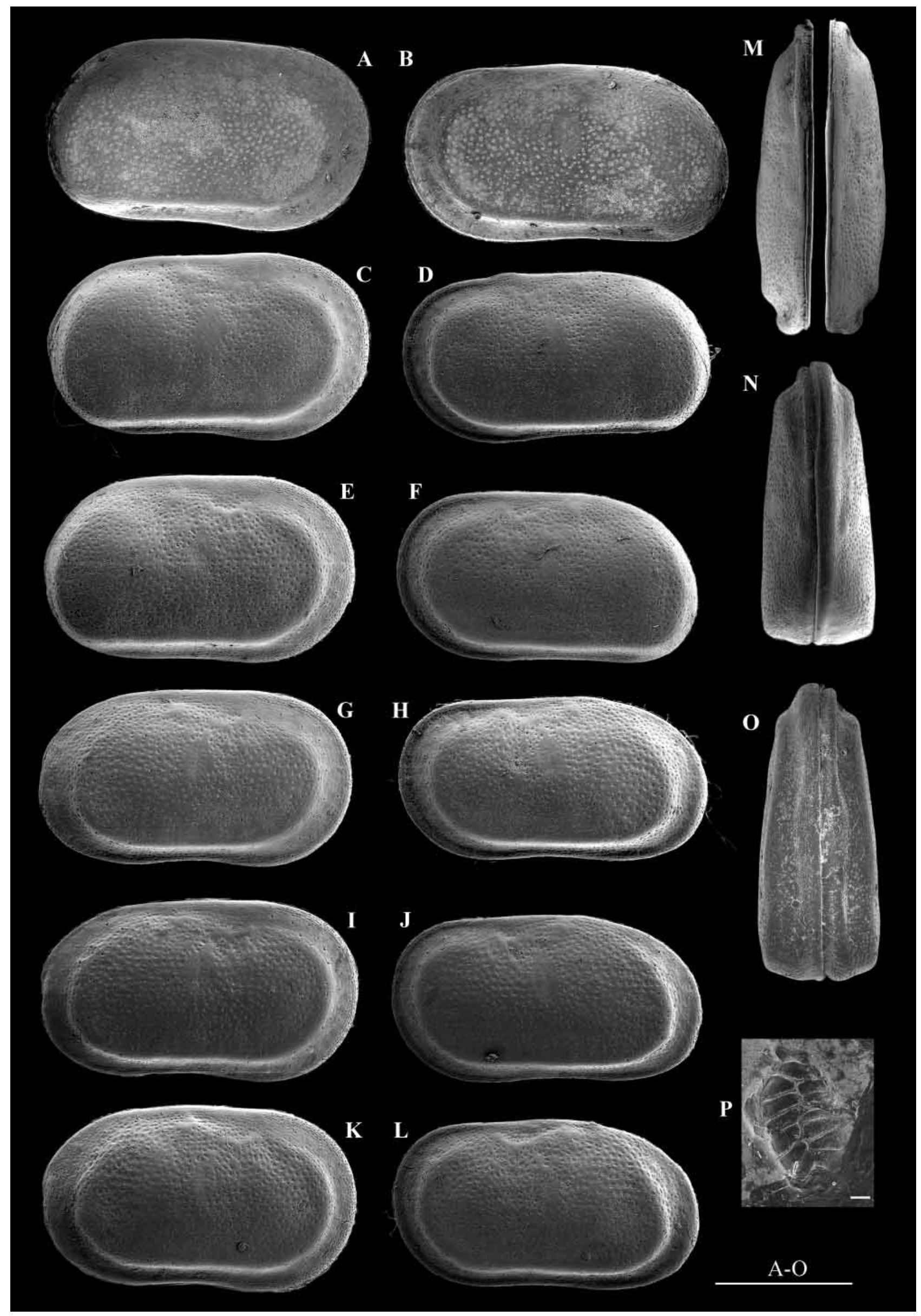




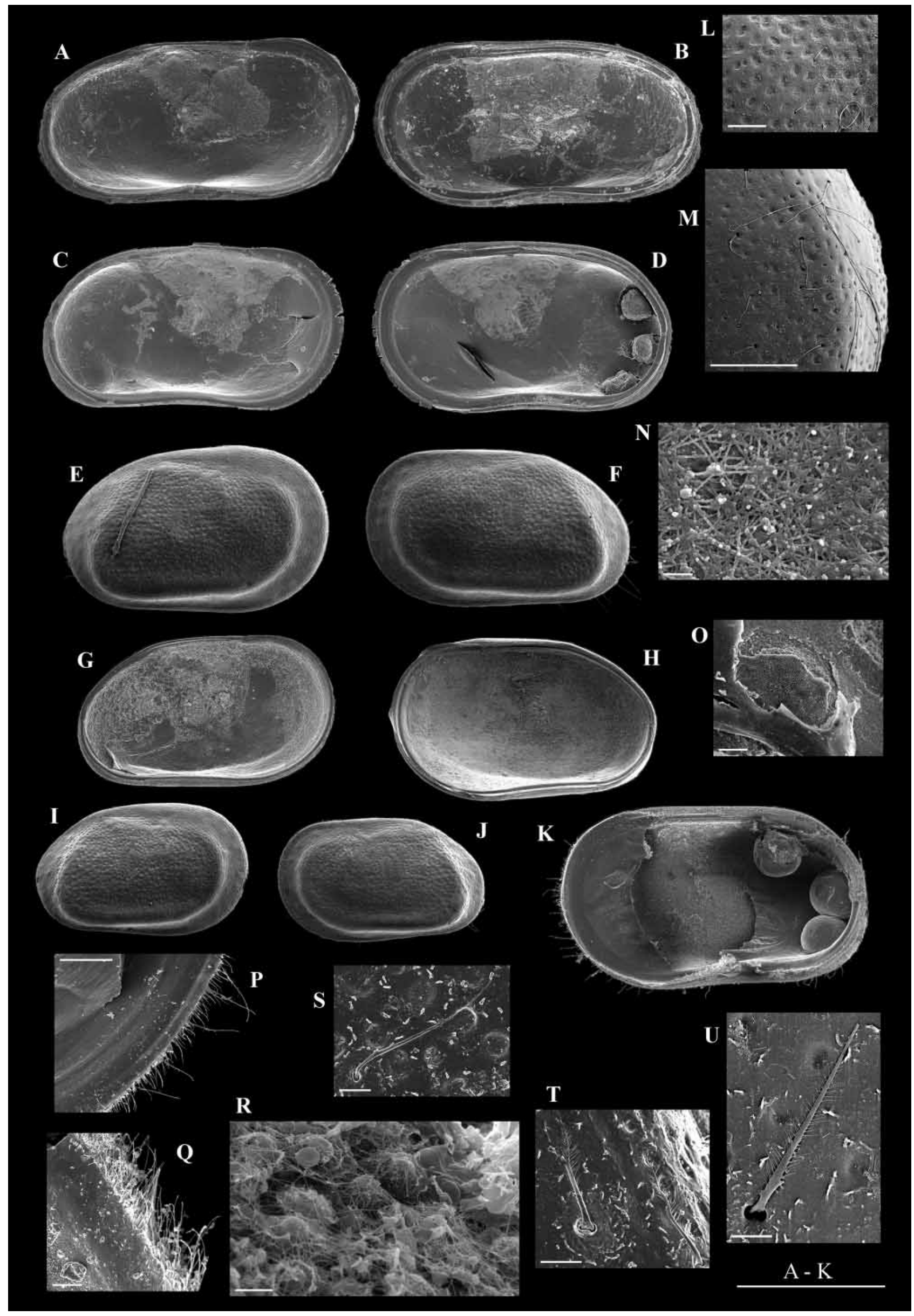


FIGURE 4. Adult and juvenile valves of Cytherella rwhatleyi sp. nov.

A, C, G, LV iv; B, D, H, K, RV iv; E, I, RV ev; F, J, LV ev; L, ornamentation of medio-dorsal area of external surface of RV; M, long setae and ornamentation on posterior of RV; $\mathbf{N}$, chitin mesh of outer lamella; $\mathbf{O}$, detail of a muscle scar; $\mathbf{P}, \mathbf{Q}$, selvage iv; $\mathbf{R}$, chitin fibres beneath the endocuticule of the outer lamella; $\mathbf{S}-\mathbf{U}$, sensilla.

A, B, paratype adult male (ZMH K-41282, SNB 0133); C, D, paratype adult female (ZMH K-41282, SNB 0018); E, F, paratype (A-1) (ZMH K-41286, SNB 0688); G, H, paratype (A-1) (ZMH K-41286, SNB 0691); I, J, S, T, paratype (A-?2) (ZMH K-41286, SNB 0689); K, P, paratype adult female (ZMH K-41286, SNB 0692); L, paratype adult male (ZMH K-41286, SNB 0170); M, paratype adult female (ZMH K-41283, SNB 0136); N, O, Q, R, paratype adult female (ZMH K-41288, SNB 0697); U, paratype adult female

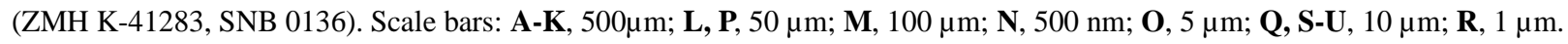

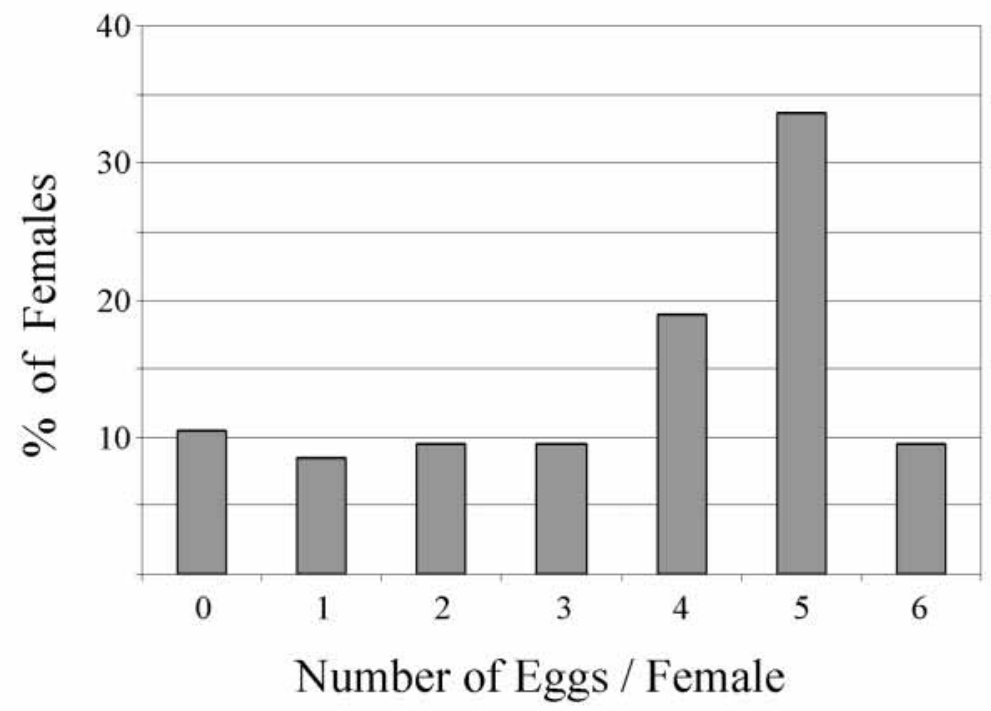

FIGURE 5. Number of eggs brooded by single females of Cytherella rwhatleyi sp. nov.

Absolute values on table 2 .

Remarks. Several specimens from the ANDEEP \# 153-7 were parasited by ?fungi and ?bacteria (Fig. 6.L$\mathrm{N})$.

The types of Cytherella serratula (Brady, 1880) (Fig. 9) from West Indies (713m depth) can be differentiated from Cytherella rwhatleyi sp. nov., because the last species has a more quadrate outline, with straighter posterodorsal margin, punctuate external surface (anteriorly and posteriorly) and do not present small tubercles in the posterior part of valves.

The only other known recent Subantarctic (Atlantic Sector) species, Cytherella hermargentina Whatley et al. 1998 (Fig. 1.2 herein), is comparatively higher with more rounded outline than the new species.

Swanson et al. (2005) described seven new species and two new genera of Cytherellidae from the Tasman Sea and from the Indic / Pacific sector of the Southern Ocean (Fig. 1.1, 3, 4, 5, 6, 8, 9). Five of these species belong to the genus Cytherella: C. hiatus Swanson et al. 2005, C. intonsa Swanson et al. 2005, C. corpusculum Swanson et al. 2005, C. plusminusve Swanson et al. 2005, C. permutata Swanson et al. 2005. These last five species lack wide rim on the lateral surface of valves, an important diagnostic character of the new species decribed here.

Cytherella rwhatleyi sp. nov. differs from the Cytherella species recorded by Whatley \& Coles (1987) (as C. serratula) from the Quaternary of North Atlantic (Deep Sea Drilling Project, site 607, 3427m) (Fig. 6.7), in ornamentation (punctuation on the entire valve surface versus tubercles just on the posterior), and shape of the dorsal margin (fairly straight versus slightly convex), and the posterior margin (steeper dorsally versus subhemispherical). 
Dingle et al. $(1989,1990)$ also reported [sic] C. serratula from Southeastern Atlantic (1000 to 2070m) (Fig. 1.10) and Mazzini (2005) illustrated a similar species from Emerald Basin (Southern Ocean, Indic Pacific Sector) (Fig. 1. 18). Both species lack surface punctation, are much higher in relation to length, and present more broadly rounded RV and more narrowly rounded posteroventral margin than $C$. rwhatleyi sp. nov.

Cytherella hemipuncta Swanson, 1969 described from the Miocene of New Zealand present irregularly spaced punctae, which are larger than the punctae of Cytherella rwhatleyi sp. nov. Cytherella rwhatleyi sp. nov. is similar in shape to $C$. cf. hemipuncta Swanson, 1969 recorded by Ayress (1995) from the Eocene of New Zealand, but the latter lacks the wide rim on the lateral valve surface.

Cytherella rwhatleyi sp. nov. can be distinguished from the Cytherella species recorded by Majoran \& Dingle (2002) from the Maud rise (Weddell Sea) (Fig. 1.14), owing to the more subquadrate outline and relatively straight dorsal margin of the former.

Cytherella sp. 4796 from the Oligocene of Victoria Land Basin, Antarctica (77S, 63E) (Dingle \& Majoran, 2001) (Fig. 1.11) has a more rounded outline than the new species described herein.

The oldest record of a cytherellid in Antarctica dates from the Campanian (Upper Cretaceous) of James Ross Island, where Fauth et al. (2003) recorded two undescribed Cytherella species (Fig. 1.12). Cytherella sp. 1 resembles $C$. rwhatleyi sp. nov in outline, but the former has a more concave ventral margin, whereas the outline of $C$. sp. 2 is much more rounded than that of the new species. Furthermore, both cretaceous species lack the conspicuous rim of $C$. rwhatleyi sp. nov.

Majoran \& Dingle (2001a) recorded Cytherella sp. from the Southwestern South Atlantic (Deep-Sea Drilling Project/Ocean Drilling Program sites 329, 513 and 699) (fig. 1.13). Cytherella rwhatleyi sp. nov. has a more quadrate outline and straight dorsal margin, while $C$. sp. (Majoran \& Dingle 2001a, pl. 1.6) is more rounded with a convex dorsal margin.

Cytherella pleistocenica Berge et al. 2007 differs from the new species described herein by the absence of the wide rim of valves.

Cytherella rwhatleyi sp. nov. is very similar to Cytherella santosensis Bergue et al. 2007 described from the Late Quaternary Santos Basin (SW Atlantic, off Southeastern Brazil) in the presence of the wide rim on the anterior, ventral and posterior areas of the valve surface (Fig. 1.20), but the outline of the former species is more equilateral, with less broadly rounded anterior margin. Furthermore, the centrodorsal area of lateral surface is more steeply elevated and the ornamentation is stronger in C. rwhatleyi than in C. santosensis. The similarity between these two spp. (valve outline, wide rim, and punctate lateral surface), one in the Southern Ocean, the other occurring in the Southwestern Atlantic demonstrates a possible migration route, made facilitated by the deep-water currents. A large quantity of the deep waters in the world has its origin in the Weddell Sea, where the new sp. described herein occurs. There the surface water is cooled and sinks to the ocean bottom, migrating then northwards in the Atlantic, Pacific and Indic Oceans (Tomczak \& Godfrey 2002). Otherwise it seams that the velocity, and probably also the frequency, in which the migration occurs is not high enough to maintain the genetic flux between two populations, one in the South Atlantic and the other in the Weddell Sea. As a consequence of that, allopatric speciation occurred and we observe similar but easily differentiable species, one in the Atlantic and the other in the Weddell and Scotia Seas.

FIGURE 6. "Soft parts" of Cytherella rwhatleyi sp. nov.

A, C, modified setae of AII (not aesthetasc); B, AII; D, Md; E, Md endites; F, MxI and female ApV; G, male ApV; H, Fu; I, posterior of female (showing body segementation, posterior dimorphic setae, genital lobe, Fu and eggs); J, genital lobe; K, details of distal part of posterior dimorphic setae (inserted on posterior segments of body); L-N, body posterior and comb setae of specimen parasited by ?fungi and ?bacteria.

A-F, H, K, paratype adult female (SNB 0698); G, paratype adult male (ZMH K-41288, SNB 0694); I, J, paratype adult female (SNB

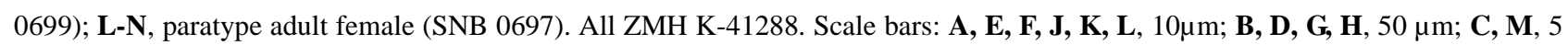
$\mu \mathrm{m} ; \mathbf{I}, 100 \mu \mathrm{m} ; \mathbf{N}, 500 \mathrm{~nm}$. 


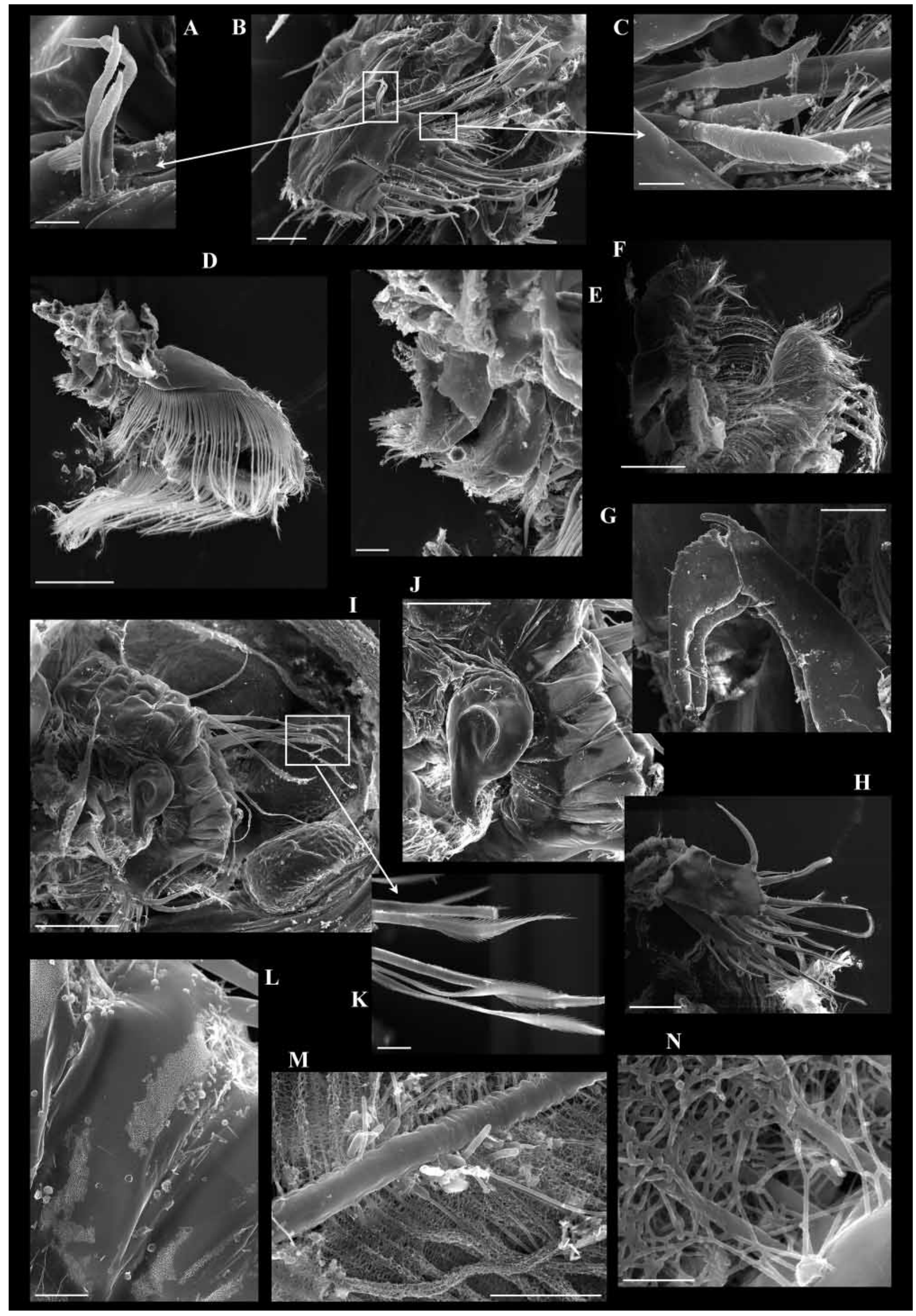

FIRST RECORD OF A LIVING PLATYCOPIDA FROM ANTARCTIC WATERS

Zootaxa 1866 (C) 2008 Magnolia Press · 359 


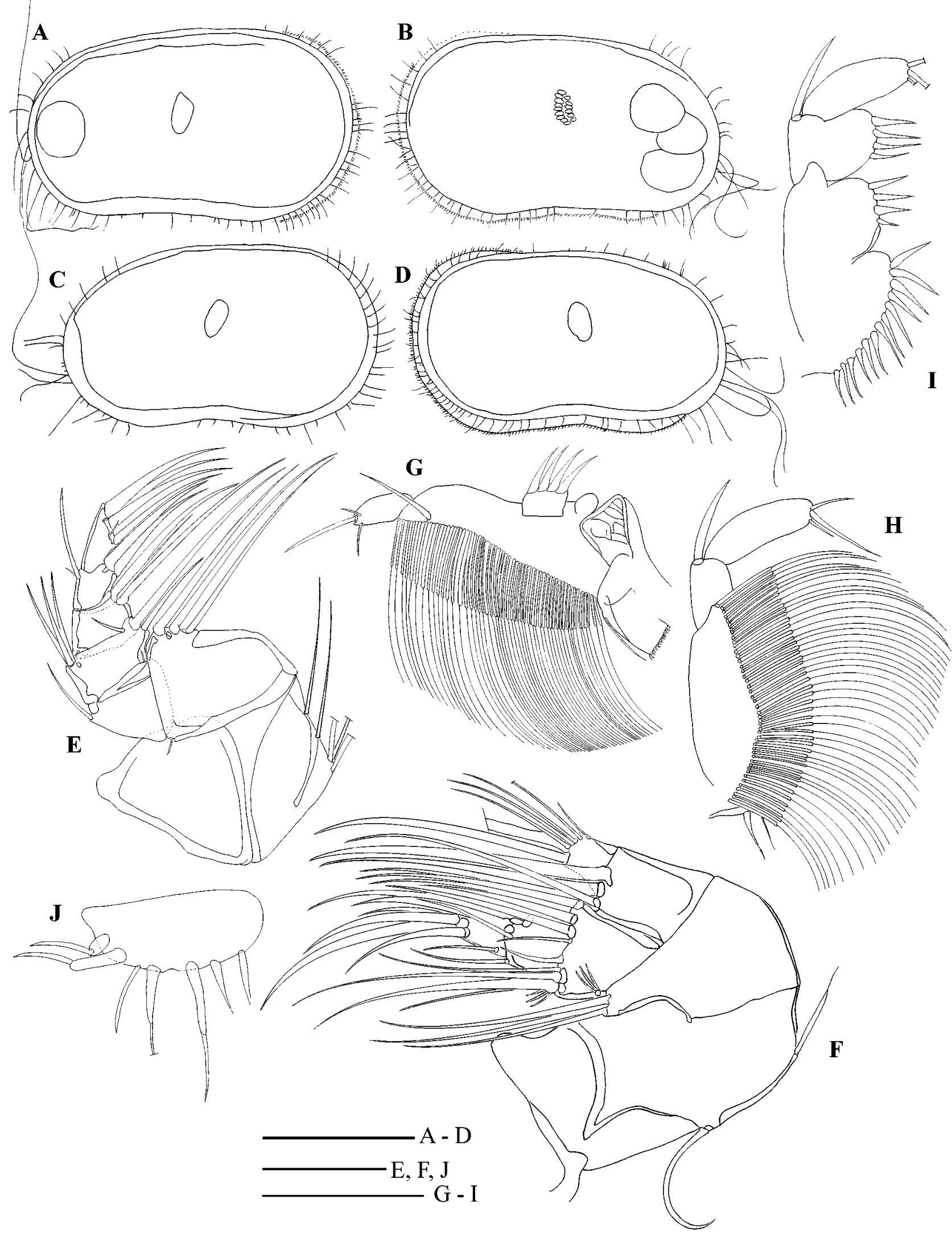

FIGURE 7. Valves and appendages of Cytherella rwhatleyi sp. nov.

A, C, RV ev; B, D, LV ev; E, AI, F, AII, G, Md; H, MxI (ventral setae not shown); I, MxI (comb setae not shown); J, female ApVI. A, B, paratype adult female (ZMH K-41284, SNB 0158); C, D, paratype adult male (ZMH K 41284, SNB 0159); E-G, holotype adult male (ZMH K-41280, SNB 0131); H, I, paratype adult female (ZMH K-41282, SNB 0134); J, paratype adult female (ZMH K-41283, SNB 0136). Scale bars: A-D, $500 \mu \mathrm{m} ; \mathbf{E}-\mathbf{J}, 100 \mu \mathrm{m}$. 


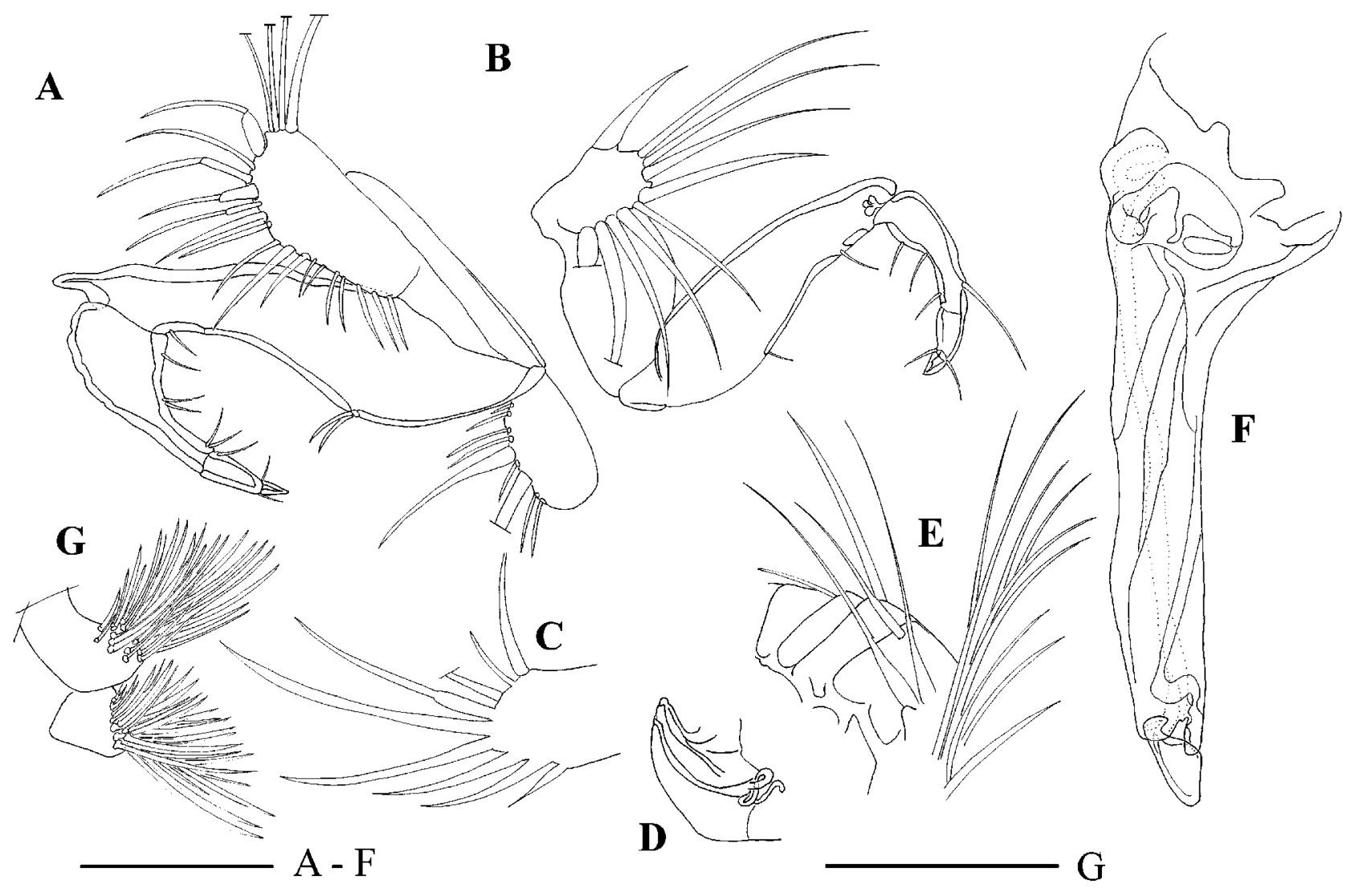

FIGURE 8. Appendages and genitalia of Cytherella rwhatleyi sp. nov.

A, male ApV; B, male ApVI; C, furca; D, genital lobe; E, Posterior dimorphic setae; F, hemipenis; G, brush-shaped organ.

A, B, G, F, holotype adult male (ZMH K-41280, SNB 0131); C-E, paratype adult female (ZMH K-41282, SNB 0134). Scale bars: 100 $\mu \mathrm{m}$.

\section{Cytherella serratula (Brady, 1880)}

(Figs. 9.A-I, 10, Tab. 3)

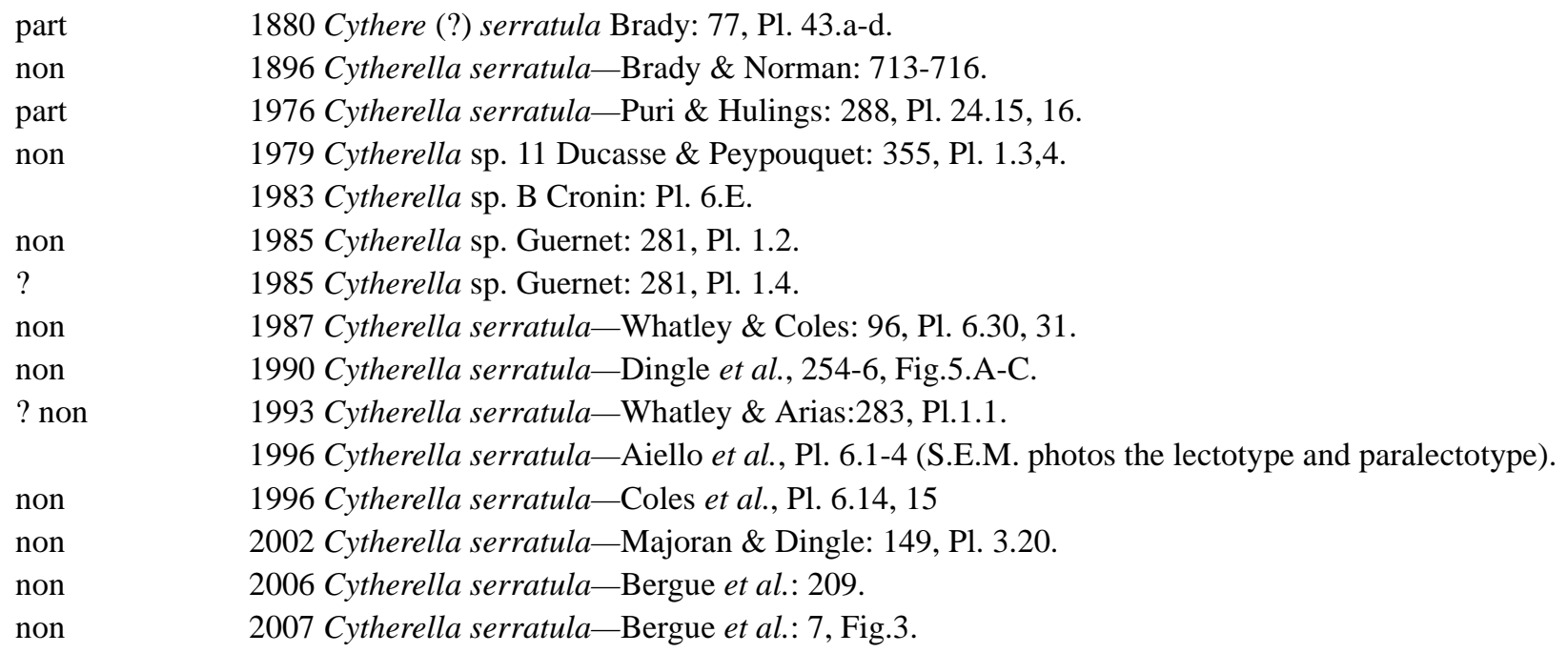

Material. Lectotype: Cythere serratula Brady, $1 \mathrm{RV}$, contained on the Challenger slide no. 173, labelled “Challenger, No. 24, D. 390, H. S. Puri 9/67, 100", BMNH cat. no. 80.38.113. The Challenger \#24 is located 
off Culebra Island, West Indies, 390fms $(=713 \mathrm{~m})$. This specimen was designated lectotype and described by Puri \& Hulings (1976: 288-289, Pl. 24.15-16), also examined and figured by Aiello et al. (1996, pl. 6.2-4). Herein this lectotype is illustrated in Fig. 9.A-D.

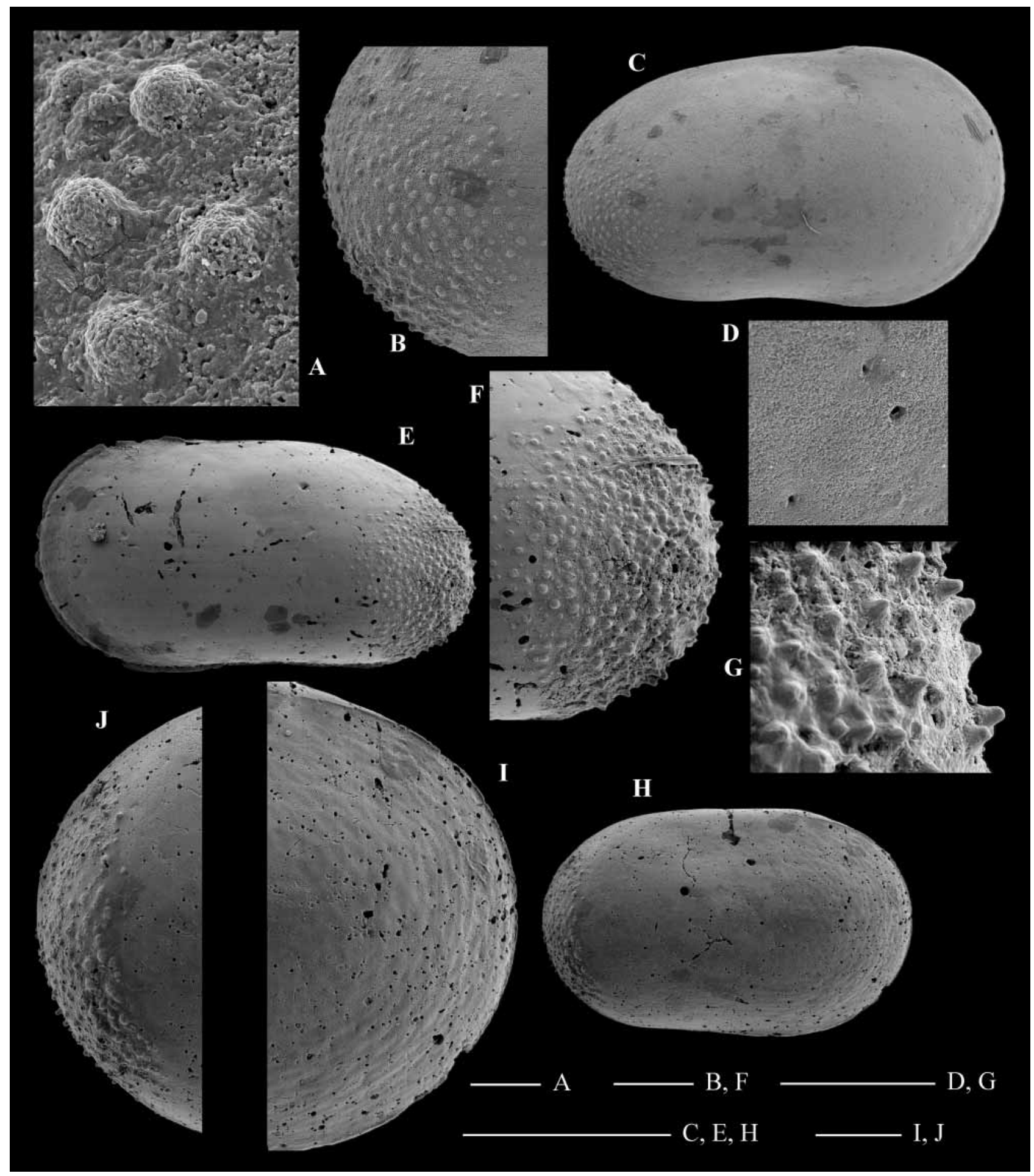

FIGURE 9. Valves of Cytherella serratula (Brady, 1880) (lectotype and paralectotype) and Cytherella sp.

Cytherella serratula (Brady, 1880) - Lectotype RV (BM 80.38.113): A, B, posterior ornamentation; C, ev; D, pore canals. Paralectotype LV (BM 80.38.113): LV; E, ev; F, G, posterior ornamentation.

Cytherella sp. (BM 80.38.113): H, RV ev; J, posterior ornamentation; I, anterior ornamentation.

Scale bars: A, $10 \mu \mathrm{m} ; \mathbf{B}, \mathbf{F}, \mathbf{I}, \mathbf{J}, 100 \mu \mathrm{m}, \mathbf{C}, \mathbf{E}, \mathbf{H}, 50 \mu \mathrm{m} ; \mathbf{D}, \mathbf{G}, 50 \mu \mathrm{m}$. 
Paralectotype: Cythere? serratula Brady, $1 \mathrm{LV}$, contained on a second Challenger slide with the same no. 173, labelled "Challenger, No. 24, D. 390, H. S. Puri 9/67, T, 100", BMNH cat. no. 80.38.113. This specimen was designated paralectotype and described by Puri \& Hulings (1976: 288-289), it was also examined and figured by Aiello et al. (1996, pl. 6.1). Herein this paralectotype is illustrated in Fig. 9.E-G.

Distribution. Recent. Off Culebra Island, Northwestern Atlantic, $713 \mathrm{~m}$.

V Measurements. Lectotype: RV, ?A L 1.10mm, H 0.64mm. Paralectotype LV, ?A L 1.08mm, 0.57mm.

Diagnosis. Valve sub-reniform in lateral view, anterior margin more broadly rounded than posterior, ventral margin concave; maximum height anterior to mid-length. Most of lateral surface smooth, except by medio-posterior area with small, sub-conic tubercles. Pore canals simple, without rim. Internally without limen. Flange well developed in LV.

Remarks. The above 15 publications dealing with deep-sea ostracods have figured or cited the occurrence of cytherellid specimens, which were assigned to the supposedly widely distributed species Cytherella serratula (Fig. 10). The total range of all these records would then include slope to abyssal depths in the North and South Atlantic, Mediterranean Sea, Indic and Southern oceans, with a geological record which extends from the Eocene to Recent. As previously stated by Majoran \& Dingle (2002), the authors responsible for these records followed "the relatively broad species concept of Cytherella serratula" (Majoran \& Dingle 2002:149). This species concept would then include (Tab. 3, Fig. 10):

Outlines ranging from very elongated (Whatley \& Arias 1993) to subquadrate (Dingle et al. 1990); with length / height rations varying from 1.53 to $2.11 \mathrm{in} \mathrm{LV}$ and from 1.55 to $1.83 \mathrm{in} \mathrm{RV}$.

Very sinuous (Majoran \& Dingle 2002) to continuously and smoothly rounded valve outline (Guernet 1985);

Posterior ornamentation varying from small inconspicuous tubercles (Dingle et al., 1990) to strongly pustulose (Majoran \& Dingle 2002);

Anterior valve surface varying from smooth (Dingle et al., 1990) to strongly pustulose (Majoran \& Dingle 2002).

Except for the diagnostic characters of the genus Cytherella, the only character uniting all specimens included in C. serratula "sensu lato" is the presence of some (highly variable) kind of posterior ornamentation. However, the presence of tubercles or pustules on the posterior surface of valves can not be used as the sole diagnostic character of any Cytherella species, since this ornamentation is present in many other described and well characterized species of the same genus. Examples include: Cytherella cercinata Aiello et al., 1996 (Miocene and Pliocene; Greece and Italy), Cytherella vulgata Ruggieri, 1962 (Miocene; Italy), Cytherella vulgatella Aiello et al., 1996 (Miocene to recent; Mediterranean Sea, Italy and Spain), and Cytherella robusta Colalongo \& Pasini, 1980 (Pliocene to recent; Italy, Greece, Mediterranean). Unfortunately, without examining all the material previously analysed by different authors, it is impossible to determine the range of intraspecific variation in the different characters, since most authors illustrate 1 or 2 specimens, and except by Aiello et al., 1996) no micrographs of the ornamentation on different regions of the valve surface are provided.

Study of the present material (C. rwhatleyi sp. nov.) and comparative studies of SEM-photos of deep-sea Cytherella in the literature (Swanson et al. 2005), confirm that the degree of intraspecific variability is much lower than previously thought. The valves of Cytherella rwhatleyi sp. nov. from the 4 different stations (Fig. 3 ), which are almost 60 of longitude and 10 of latitude apart, display very few intra- and interpopulational variability. Furthermore, a closer look at the publications on deep-sea ostracods shows that many deep-sea ostracodologists have adopted 2 different ways while defining deep-sea species. In one hand side are the species described in the $19^{\text {th }}$ Century (mostly Brady 1880). For these first species, a very wide intraspecific morphological variability is allowed, most probably because authors are convinced that deep-sea ostracod species are cosmopolitan (Whatley \& Ayress 1988), and they expect to find the cosmopolitan taxa in samples from different basins. Furthermore, the illustrations and descriptions provided in the $19^{\text {th }}$ century are so simple that 
very different specimens may be included in each species. In the other hand side are the species described in the second half of the $20^{\text {th }}$ Century, which are "kept" more or less endemic, (in my opinion) because authors do not expect to find them in localities distant from where they were collected, but also importantly because the SEM illustrations provide much more information, avoiding that too different specimens are assigned to these species.

Consequently, I consider Cytherella serratula (Brady, 1880) to be restricted to bathyal depths of Northwestern Atlantic (Type locality - Brady, 1880, Puri \& Hulings 1976, and Aiello et al. 1996; and probably U. S. continental slope-Cronin, 1983). Meanwhile, more subquadrate forms, with larger height / length ratios known from the North Atlantic (Ducasse \& Peypouquet 1979, Whatley \& Coles 1987, Coles et al. 1996) and Southeastern Atlantic (Dingle et al. 1990), and more elongated forms from Northeastern Atlantic (Brady \& Norman 1896), from the Indic Ocean (Guernet 1985) and Mediterranean Sea (Whatley \& Arias 1993) should be assigned to different species. Similarly, forms with conspicuously sinuous outline collected from the Indic (Guernet 1985), and the Southern Ocean (Majoran \& Dingle 2002) should also be described as different taxa.

TABLE 3. Comparison of morphological characters in different specimens of Cytherella serratula (Brady, 1880).

\begin{tabular}{|c|c|c|c|c|c|c|}
\hline Author & Locality & Age & $\begin{array}{c}\text { Recent* } \\
\text { Depth (m) }\end{array}$ & $\begin{array}{l}\text { General } \\
\text { Form }\end{array}$ & $\begin{array}{l}\text { RV - Length / } \\
\text { height (mm); } \\
\text { Ratio L/H }\end{array}$ & $\begin{array}{l}\text { LV - Length / } \\
\text { height (mm) }\end{array}$ \\
\hline $\begin{array}{l}\text { Lectotype (RV) / - Paralecto- } \\
\text { type (LV) Brady 1880; Puri } \\
\& \text { Hulings 1976; Aiello et al } \\
\text { 1996* }\end{array}$ & $\begin{array}{c}\text { Northwestern Atlantic } \\
\text { (Culebra Is., West } \\
\text { indies) }\end{array}$ & Recent & 713 & irregular & $1.01 / 0.61=1.55$ & $0.99 / 0.47=2.11$ \\
\hline Brady \& Norman 1896 & $\begin{array}{c}\text { Northeastern Atlantic } \\
\text { (off Northwestern } \\
\text { Africa) }\end{array}$ & Recent & $852-2135$ & ovate & NI & $1.05 / 0.60=1.75$ \\
\hline Bergue et al 2006 & $\begin{array}{l}\text { Southwestern Atlantic } \\
\text { (Santos Basin) }\end{array}$ & $\begin{array}{c}\text { Pleistocene } \\
\text { and Holocene }\end{array}$ & 1130 & ovate & $0.91 / 0.58=1.57$ & NI \\
\hline Coles et al 1996 & $\begin{array}{l}\text { Northeastern Atlantic } \\
\text { (Porcupine Basin) }\end{array}$ & Quaternary & $610-800$ & ovate & $1.08 / 0.65=1.67$ & $1.10 / 0.72=1.53$ \\
\hline Cronin 1983 & $\begin{array}{l}\text { Northwestern Atlantic } \\
\text { (Florida-Hatteras } \\
\text { Slope, Blake Plateau, } \\
\text { Straits of Florida) }\end{array}$ & Recent & $462-1070$ & ovate & NI & $0.97 / 0.51=1.90$ \\
\hline Dingle et al 1990 & $\begin{array}{c}\text { Southeatern Atlantic } \\
\text { (off Southwestern } \\
\text { Africa) }\end{array}$ & Recent & $2417-3022$ & ovate & $0.97 / 0.61=1.59$ & $0.96 / 0.54=1.78$ \\
\hline $\begin{array}{l}\text { Ducasse \& Peypouquet } 1979 \\
\text { (as Cytherella } \\
\text { sp. 11) }\end{array}$ & $\begin{array}{l}\text { Northeastern Atlantic } \\
\text { (Rockall Plateau) }\end{array}$ & Pliocene & $* 2371$ & ovate & $1.04 / 0.62=1.68$ & NI \\
\hline Guernet 1985 & $\begin{array}{c}\text { Indic Ocean (Ridge } \\
90 ? \mathrm{E})\end{array}$ & Eocene & 1665 & ovate & $0.79 / 0.43=1.83$ & $1.02 / 0.63=1.62$ \\
\hline Majoran \& Dingle 2002 & $\begin{array}{c}\text { Southern Ocean } \\
\text { (Maud Rise, Weddell } \\
\text { Sea) }\end{array}$ & Oligocene & - & irregular & NI & $0.83 / 0.47=1.76$ \\
\hline Whatley \& Arias 1993 & $\begin{array}{l}\text { Mediterranean Sea } \\
\quad \text { (off Libya) }\end{array}$ & Oligocene & 1948 & $\begin{array}{c}\text { very } \\
\text { elongated }\end{array}$ & $0.8 / 0.47=1.70$ & NI \\
\hline Whatley \& Coles 1987 & North Atlantic & Miocene & - & irregular & $1.10 / 0.65=1.69$ & NI \\
\hline
\end{tabular}


TABLE 3 (continued)

\begin{tabular}{|c|c|c|c|c|c|c|c|c|}
\hline \multirow{3}{*}{ Author } & \multicolumn{8}{|c|}{$\mathbf{R V}$} \\
\hline & \multirow{2}{*}{$\begin{array}{c}\text { Dorsal } \\
\text { Mg. }\end{array}$} & \multirow{2}{*}{$\begin{array}{c}\text { Ventral } \\
\text { Mg. }\end{array}$} & \multirow{2}{*}{ Ant. Mg. } & \multirow{2}{*}{ Post. Mg. } & \multirow[t]{2}{*}{ Max. H } & \multirow{2}{*}{ Max. L. } & \multicolumn{2}{|c|}{ Ornamentation } \\
\hline & & & & & & & Anterior & Posterior \\
\hline $\begin{array}{l}\text { Lectotype (RV) / - Para- } \\
\text { lectotype (LV) Brady } \\
\text { 1880; Puri \& Hulings } \\
\text { 1976; Aiello et al 1996* }\end{array}$ & inclined & $\begin{array}{l}\text { slightly } \\
\text { concave }\end{array}$ & $\begin{array}{l}\text { broadly } \\
\text { rounded }\end{array}$ & $\begin{array}{c}\text { narrowly } \\
\text { rounded }\end{array}$ & $\begin{array}{l}\text { anterior to } \\
\text { mid-length }\end{array}$ & $\begin{array}{l}\text { at mid- } \\
\text { height. }\end{array}$ & absent & $\begin{array}{c}\text { conspicuous } \\
\text { small tubercles }\end{array}$ \\
\hline Brady \& Norman 1896 & NI & NI & NI & NI & NI & NI & NI & NI \\
\hline Bergue et al 2006 & straight & $\begin{array}{l}\text { slightly } \\
\text { concave }\end{array}$ & $\begin{array}{l}\text { broadly } \\
\text { rounded }\end{array}$ & $\begin{array}{l}\text { broadly } \\
\text { rounded }\end{array}$ & $\begin{array}{l}\text { anterior to } \\
\text { mid-length }\end{array}$ & $\begin{array}{l}\text { at mid- } \\
\text { height. }\end{array}$ & faint & $\begin{array}{l}\text { conspicuous } \\
\text { small tubercles }\end{array}$ \\
\hline Coles et al 1996 & sinuous & sinuous & $\begin{array}{l}\text { broadly } \\
\text { rounded }\end{array}$ & $\begin{array}{c}\text { narrowly } \\
\text { rounded }\end{array}$ & $\begin{array}{l}\text { anterior to } \\
\text { mid-length }\end{array}$ & $\begin{array}{l}\text { below mid- } \\
\text { height. }\end{array}$ & present & $\begin{array}{l}\text { conspicuous } \\
\text { small tubercles }\end{array}$ \\
\hline Cronin 1983 & NI & NI & NI & NI & NI & NI & NI & NI \\
\hline Dingle et al 1990 & straight & $\begin{array}{l}\text { slightly } \\
\text { concave }\end{array}$ & $\begin{array}{l}\text { broadly } \\
\text { rounded }\end{array}$ & $\begin{array}{l}\text { broadly } \\
\text { rounded }\end{array}$ & $\begin{array}{l}\text { anterior to } \\
\text { mid-length }\end{array}$ & $\begin{array}{l}\text { at mid- } \\
\text { height. }\end{array}$ & faint & $\begin{array}{c}\text { absent (?) or } \\
\text { faint (?) }\end{array}$ \\
\hline $\begin{array}{l}\text { Ducasse \& Peypouquet } \\
1979 \text { (as Cytherella sp. } \\
11 \text { ) }\end{array}$ & straight & $\begin{array}{l}\text { slightly } \\
\text { concave }\end{array}$ & $\begin{array}{l}\text { broadly } \\
\text { rounded }\end{array}$ & $\begin{array}{l}\text { broadly } \\
\text { rounded }\end{array}$ & $\begin{array}{l}\text { anterior to } \\
\text { mid-length }\end{array}$ & $\begin{array}{l}\text { at mid- } \\
\text { height. }\end{array}$ & present & $\begin{array}{l}\text { conspicuous } \\
\text { small tubercles }\end{array}$ \\
\hline Guernet 1985 & $\begin{array}{l}\text { slightly } \\
\text { arched }\end{array}$ & $\begin{array}{l}\text { slightly } \\
\text { concave }\end{array}$ & $\begin{array}{l}\text { broadly } \\
\text { rounded }\end{array}$ & $\begin{array}{c}\text { narrowly } \\
\text { rounded }\end{array}$ & $\begin{array}{l}\text { anterior to } \\
\text { mid-length }\end{array}$ & $\begin{array}{l}\text { above mid- } \\
\text { height }\end{array}$ & ?present & $\begin{array}{l}\text { conspicuous } \\
\text { small tubercles }\end{array}$ \\
\hline Majoran \& Dingle 2002 & NI & NI & NI & NI & NI & NI & NI & NI \\
\hline Whatley \& Arias 1993 & $\begin{array}{l}\text { slightly } \\
\text { convex }\end{array}$ & $\begin{array}{l}\text { slightly } \\
\text { concave }\end{array}$ & $\begin{array}{l}\text { broadly } \\
\text { rounded }\end{array}$ & $\begin{array}{l}\text { broadly } \\
\text { rounded }\end{array}$ & $\begin{array}{l}\text { anterior to } \\
\text { mid-length }\end{array}$ & $\begin{array}{l}\text { at mid- } \\
\text { height }\end{array}$ & $?$ & $\begin{array}{c}\text { conspicuous } \\
\text { small tubercles }\end{array}$ \\
\hline Whatley \& Coles 1987 & $\begin{array}{l}\text { slightly } \\
\text { convex }\end{array}$ & $\begin{array}{l}\text { slightly } \\
\text { concave }\end{array}$ & $\begin{array}{l}\text { broadly } \\
\text { rounded }\end{array}$ & $\begin{array}{l}\text { broadly } \\
\text { rounded }\end{array}$ & $\begin{array}{l}\text { anterior to } \\
\text { mid-length }\end{array}$ & $\begin{array}{l}\text { at mid- } \\
\text { height }\end{array}$ & ?present & $\begin{array}{l}\text { conspicuous } \\
\text { small tubercles }\end{array}$ \\
\hline
\end{tabular}

TABLE 3 (continued)

\begin{tabular}{|c|c|c|c|c|c|c|}
\hline \multirow[b]{2}{*}{ Author } & \multicolumn{6}{|c|}{$\mathbf{L V}$} \\
\hline & Dorsal Mg. & Ventral Mg. & Ant. Mg. & Post. Mg. & Max. H. & Max. L. \\
\hline $\begin{array}{l}\text { Lectotype (RV) / - Paralec- } \\
\text { totype (LV) Brady 1880; } \\
\text { Puri \& Hulings 1976; } \\
\text { Aiello et al 1996* }\end{array}$ & $\begin{array}{l}\text { straight ant; } \\
\text { steeply } \\
\text { inclined post. }\end{array}$ & straight & $\begin{array}{l}\text { equally } \\
\text { rounded }\end{array}$ & $\begin{array}{l}\text { narrowly } \\
\text { rounded }\end{array}$ & $\begin{array}{l}\text { anterior to } \\
\text { mid-length }\end{array}$ & inferior to mid-height \\
\hline Brady \& Norman 1896 & $\begin{array}{l}\text { almost } \\
\text { straight }\end{array}$ & $\begin{array}{l}\text { slightly con- } \\
\text { cave }\end{array}$ & $\begin{array}{l}\text { broadly } \\
\text { rounded }\end{array}$ & $\begin{array}{l}\text { broadly } \\
\text { rounded }\end{array}$ & $\begin{array}{l}\text { anterior to } \\
\text { mid-length }\end{array}$ & inferior to mid-height \\
\hline Bergue et al 2006 & NI & NI & NI & NI & NI & NI \\
\hline Coles et al 1996 & sinuous & sinuous & $\begin{array}{l}\text { broadly } \\
\text { rounded }\end{array}$ & $\begin{array}{c}\text { narrowly } \\
\text { rounded }\end{array}$ & $\begin{array}{l}\text { anterior to } \\
\text { mid-length }\end{array}$ & below mid-height \\
\hline Cronin 1983 & $\begin{array}{l}\text { almost } \\
\text { straight }\end{array}$ & straight & $\begin{array}{l}\text { broadly } \\
\text { rounded }\end{array}$ & $\begin{array}{l}\text { broadly } \\
\text { rounded }\end{array}$ & $\begin{array}{l}\text { posterior to } \\
\text { mid-length }\end{array}$ & at mid-height \\
\hline
\end{tabular}


TABLE 3 (continued)

LV

\begin{tabular}{|c|c|c|c|c|c|c|}
\hline Author & Dorsal Mg. & Ventral Mg. & Ant. Mg. & Post. Mg. & Max. $H$. & Max. L. \\
\hline Dingle et al 1990 & $\begin{array}{l}\text { sinuous ant.; } \\
\text { inclined post. }\end{array}$ & $\begin{array}{l}\text { slightly con- } \\
\text { cave }\end{array}$ & $\begin{array}{l}\text { equally } \\
\text { rounded }\end{array}$ & $\begin{array}{l}\text { narrowly } \\
\text { rounded }\end{array}$ & $\begin{array}{l}\text { posterior to } \\
\text { mid-length }\end{array}$ & inferior to mid-height \\
\hline $\begin{array}{l}\text { Ducasse \& Peypouquet } \\
1979 \text { (as Cytherella } \text { sp. 11) }\end{array}$ & NI & NI & NI & NI & NI & NI \\
\hline Guernet 1985 & straight & straight & $\begin{array}{l}\text { equally } \\
\text { rounded }\end{array}$ & $\begin{array}{l}\text { narrowly } \\
\text { rounded }\end{array}$ & $\begin{array}{l}\text { posterior to } \\
\text { mid-length }\end{array}$ & at mid-height \\
\hline Majoran \& Dingle 2002 & very sinuous & $\begin{array}{l}\text { slightly con- } \\
\text { cave }\end{array}$ & $\begin{array}{l}\text { broadly } \\
\text { rounded }\end{array}$ & $\begin{array}{l}\text { narrowly } \\
\text { rounded }\end{array}$ & $\begin{array}{l}\text { anterior to } \\
\text { mid-length }\end{array}$ & inferior to mid-height \\
\hline Whatley \& Arias 1993 & NI & NI & NI & NI & NI & NI \\
\hline Whatley \& Coles 1987 & NI & NI & NI & NI & NI & NI \\
\hline
\end{tabular}

TABLE 3 (continued)

Author

Ornamentation

comments

\begin{tabular}{|c|c|c|c|}
\hline \multirow[t]{2}{*}{ Author } & \multicolumn{2}{|c|}{ Ornamentation } & \multirow[t]{2}{*}{ comments } \\
\hline & Anterior & Posterior & \\
\hline $\begin{array}{l}\text { Lectotype (RV) / - Paralectotype } \\
\text { (LV) Brady 1880; Puri \& Hul- } \\
\text { ings 1976; Aiello et al } 1996^{*}\end{array}$ & absent & $\begin{array}{l}\text { small tuber- } \\
\text { cles }\end{array}$ & \\
\hline Brady \& Norman 1896 & absent & ?present & $\begin{array}{l}\text { The specimens illustrated by Brady \& Norman (1896) are conspicuously more } \\
\text { equilateral (with broadly rounded posterior) than the type of } C \text {. serratula. }\end{array}$ \\
\hline Bergue et al 2006 & NI & NI & Larger height/length ratio than lectotype of $C$. serratula. \\
\hline Coles et al 1996 & present & $\begin{array}{l}\text { conspicu- } \\
\text { ous small } \\
\text { tubercles }\end{array}$ & $\begin{array}{l}\text { The illustrated specimens are conspicuously higher in relation to length than the } \\
\text { types of } C \text {. serratula. }\end{array}$ \\
\hline Cronin 1983 & ?present & $\begin{array}{l}\text { conspicu- } \\
\text { ous small } \\
\text { tubercles }\end{array}$ & $\begin{array}{l}\text { Cronin (1983) identified the specimens as Cytherella sp. B. Afterwards, Aiello et } \\
\text { al (1996) assigned them to C. robusta Colalongo \& Pasini, 1980. Otherwise, Ber- } \\
\text { gue et al (2007) assigned them to C. serratula. }\end{array}$ \\
\hline Dingle et al 1990 & present & $\begin{array}{l}\text { absent (?) or } \\
\text { faint (?) }\end{array}$ & $\begin{array}{l}\text { The specimens from the analysed in this publication differ considerably from the } \\
\text { type specimens of this species: south Atlantic specimens present (1) more equilat- } \\
\text { eral outline in lateral view; (2) much more faint (or even absence) posterior orna- } \\
\text { mentation; (3) and presence of anterior ornamentation. }\end{array}$ \\
\hline $\begin{array}{l}\text { Ducasse \& Peypouquet } 1979 \text { (as } \\
\text { Cytherella sp. 11) }\end{array}$ & NI & NI & $\begin{array}{l}\text { Ducasse \& Peypouquet (1979) identified the specimens as Cytherella sp. } 11 . \\
\text { Afterwards, Aiello et al ,1996 identified them as C. robusta Colalongo \& Pasini, } \\
\text { 1980. Otherwise, Bergue et al (2007) assigned them to Cytherella serratula. }\end{array}$ \\
\hline Guernet 1985 & absent & $\begin{array}{l}\text { conspicu- } \\
\text { ous small } \\
\text { tubercles }\end{array}$ & $\begin{array}{l}\text { The } 2 \text { valves illustrated by Guernet (1985) most probably belong to } 2 \text { different } \\
\text { species, both of them differing considerably from the lectotypes of C. serratula. }\end{array}$ \\
\hline Majoran \& Dingle 2002 & pustulose & pustulose & $\begin{array}{l}\text { The specimens illustrated by Majoran \& Dingle (2002, pl. 3.20) present more arc- } \\
\text { uate dorsal margin and concave ventral margin than the lectotype of C. serratula. }\end{array}$ \\
\hline Whatley \& Arias 1993 & NI & NI & $\begin{array}{l}\text { The illustrated specimens much more elongated (smaller length / height ratio) then } \\
\text { the lectotype of C. serratula. }\end{array}$ \\
\hline Whatley \& Coles 1987 & NI & NI & $\begin{array}{c}\text { These specimens is heigher in relation to length and present more arcuate dorsal } \\
\text { margin than the lectotype of C. serratula. }\end{array}$ \\
\hline
\end{tabular}




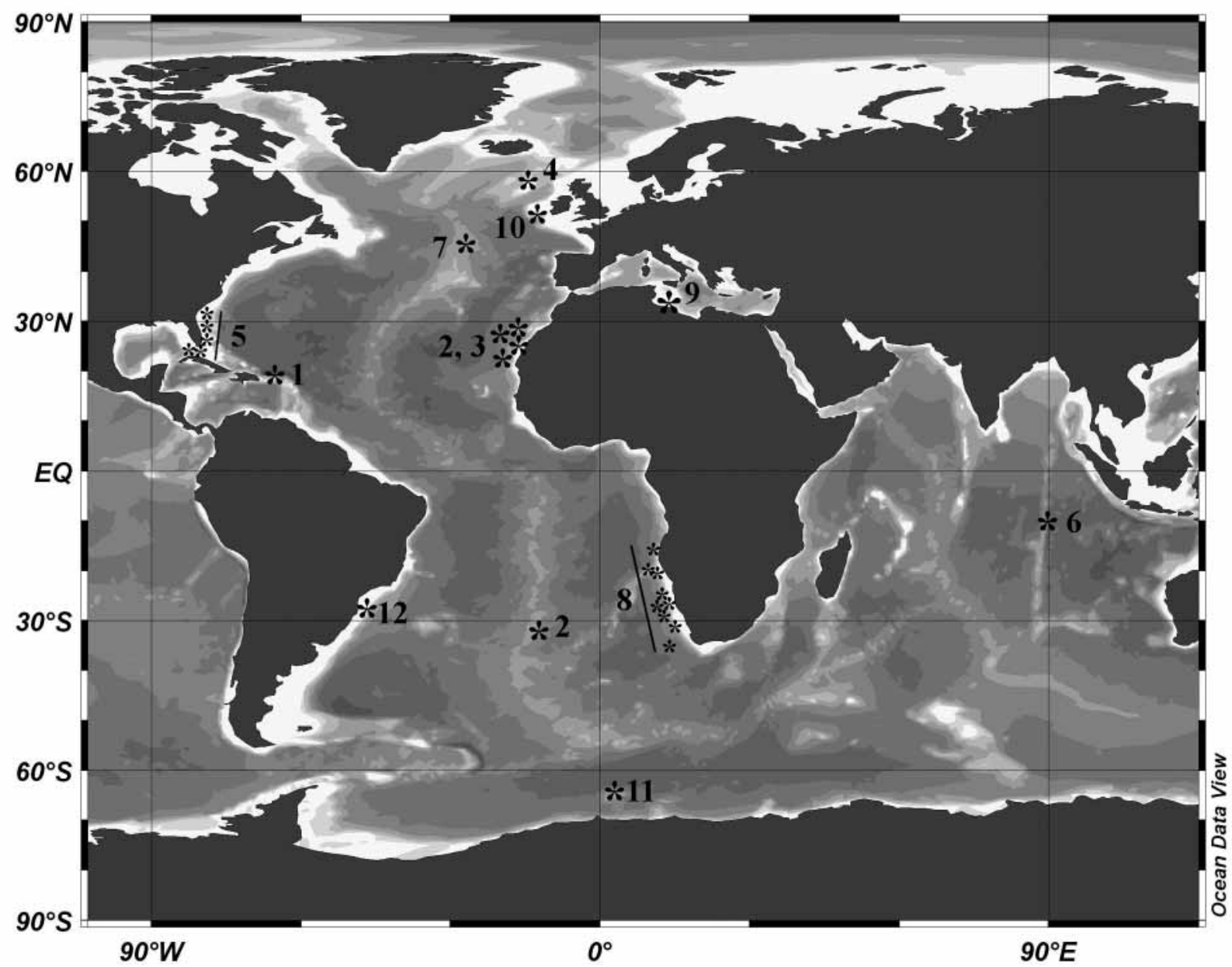

FIGURE 10. Published occurrences of Cytherella serratula (Brady, 1880).

1 - Type locality, from Brady (1880) and Puri \& Hulings (1976); 2—from Brady 1880; 3-from Brady \& Norman 1896; 4 -from Ducasse \& Peypouquet 1979; 5 - from Cronin 1983; 6 - from Guernet 1985; 7-from Whatley \& Coles, 1987; 8-from Dingle et al., 1990; 9-from Whatley \& Arias, 1993; 10—from Coles et al., 1996; 11—from Majoran \& Dingle, 2002; 12_from Bergue et al. (2007).

\section{Cytherella sp.}

(Fig. 9.H-J)

Part 1976 Cytherella serratula®Puri \& Hulings: 288.

Material. This RV was together with the paralectotype of Cytherella serratula on a slide labelled "Cythere? serratula Brady, 173, Challenger, No. 24, D. 390, H. S. Puri 9/67, T, 100”, BMNH cat. no. 80.38.113.” But according to Puri \& Hulings (1976: 289) this RV was most probably collected from the Challenger station 85 (see below).

Distribution. Recent. Off Canaries Island, Northeastern Atlantic, 2057m.

$V$ Measurements. RV, L $0.90 \mathrm{~mm}, \mathrm{H} 0.57 \mathrm{~mm}$.

Remarks. According to Puri \& Hulings (1976: 289) the following material was included in the Challenger type material of the species $C$. serratula: "The lectotype [of $C$. serratula] a right valve, is from Stat. 24. Topotypic material: a left valve, BM 1974.387, was picked from the sediment sample M-44 (Stat. 24). Two small specimens recovered from sediment sample M-106 (Stat. 85, off Canaries, 1125 fathoms) may belong to this species". So I suppose that this smaller RV (which was in the same micropaleontological slide as the paralectotype of $C$. serratula) was actually collected at the Challenger station 85 and not 24 (as stated in the slide 
label). Cytherella sp. (Fig. 9.H-J) differs from Cytherella serratula (Brady, 1880) (Fig. 9.A-G) because the former species present the anterior area of valve lateral surface with shallow, elongate punctae arranged in concentric rows which are parallel to anterior valve margin. Additionally, Cytherella sp. is higher in relation to length and more equilateral than Cytherella serratula.

\section{Discussion}

\section{Morphology and Geographical Distribution}

Contrary to most of the platycopids (Horne et al. 2002), males of Cytherella rwhatleyi sp. nov. have a brush-shaped organ (Fig. 8E). Other records of brush-shaped organs in cytherellids include four species of Cytherella and one species of Cytherelloidea (Schulz 1976, Figs. 2, 12, 18; Swanson et al. 2005, Figs. 3G, 5D). Since the brush-shaped organ is present in most of the infrarders of Podocopa (Bairdiocopina, Cytherocopina, Cypridocopina) and also in only the five platycopid species (in two genera) an epigenetic control of this character is suggested herein. In this way, the expression of that organ could have been turned "off" before the origin of the platycopids, but was subsequently "turned on" in this few cytherellids.

The genus Cytherella was already quite widespread in the southern hemisphere during the Cretaceous and early Cenozoic, and records involve, for example, Southern Africa (Dingle 1984), Antarctic Peninsula (Fauth et al. 2003), Maud Rise (Majoran et al. 1997), New Zealand (Ayress 1995). Somehow surprising, is then the low number of recent deep-sea Cytherella species reported from the Atlantic Sector of the Southern Ocean and from the South Atlantic: few species from the South Atlantic, and only Cytherella rwhatleyi from the continental margin off Antarctica. Otherwise, a considerably higher diversity of recent deep-sea platycopids (12 species in 3 genera) exists nowadays on the Southwestern Pacific (Jellinek \& Swanson 2003). This picture might be related to the large sampling effort related with several projects (e.g. TASQWA, see Jellinek \& Swanson 2003), which focused on the continental margins and plateaus from the Southwestern Pacific. In the Atlantic Ocean and on the Antarctic continental margin a considerable smaller number of samples from recent sediments have been collected, or at least studied and published. Otherwise, considering the Antarctic margin, it is possible that the extremely low temperatures existing since millions of years might have been responsible for the extinction of platycopid lineages, which were present there during the warmer Cretaceous (Majoran $e t$ al. 1997). Additionally, some environmental parameter related to depth appear to be prohibitive for platycopids, which are widespread in the continental shelves and margins of most continents, but are almost absent in abyssal plains. In this way, the abyssal plains seam to be biogeographical barriers to the Cytherella species and as a result each continental region tends to present its own fauna. Furthermore, considering the Southwestern Pacific, the northward currents present at the intermediate depths seam to represent a barrier to EastWest dispersion of cytherellids, since different species are found on each side of New Zealand (Fig. 10).

The large number of live specimens available herein made an evaluation on the intraspecific morphological variability in a deep-sea cytherellid species possible. This evaluation provides a base which can be used for the definition of subfossil and fossil species morphological range in platycopids. This morphological range will then be important for the correct identification of specimens, essential to biodiversity, genetic, paleoenvironmental, and geochemical studies. In the case of Cytherella rwhatleyi sp. nov., little if any intrapopulational (same station) or interpopulational (different stations) variation in outline and ornamentation of valves (Figs. $3,4)$ and on the hemipenis was observed. Few papers provide SEM-photos of several specimens of the same species, however, a similar lack of carapace variability can also be seen in the literature (Swanson et al., 2005). These observations contradict the actual very broad intraspecific morphological variability accepted by most researchers in studies about deep-sea ostracods. 
2. Platycopids and $\mathrm{O}_{2}$ concentration in water masses

The present study is a good opportunity to test the theory on the relationship between the $\mathrm{O}_{2}$ concentration in water masses and the numerical abundance of filter feeding ostracods (including the genus Cytherella). According to Whatley (1991, 1995, Whatley et al. 2003), the higher ecological success of the Cytherella during kenoxic/anoxic events would be related to the higher circulation of water inside the carapace, used for the filter feeding. Furthermore, eggs brooded by the female inside of the carapace, would have higher survival chances than eggs lain in the environment (Jarvis et al. 1998). The following scale on the relationship between the percentage of platycopid specimens and the $\mathrm{O}_{2}$ concentration was proposed (Whatley et al. 2003):

$>90 \%$ platycopids $=<1.5 \mathrm{ml} / 1 \mathrm{O}_{2}(\sim 67 * \mu \mathrm{mol} / \mathrm{kg})$;

$80-90 \%$ platycopids $=2.0-1.5 \mathrm{ml} / 1 \mathrm{O}_{2}(\sim 89 *-67 * \mu \mathrm{mol} / \mathrm{kg})$;

$70-80 \%$ platycopids $=2.5-2.0 \mathrm{ml} / 1 \mathrm{O}_{2}(\sim 112 *-89 * \mu \mathrm{mol} / \mathrm{kg})$;

$60-70 \%$ platycopids $=3.0-2.5 \mathrm{ml} / 1 \mathrm{O}_{2}\left(\sim 134^{*}-112 * \mu \mathrm{mol} / \mathrm{kg}\right)$;

$50-60 \%$ platycopids $=3.5-3.0 \mathrm{ml} / 1 \mathrm{O}_{2}\left(\sim 156^{*}-134 * \mu \mathrm{mol} / \mathrm{kg}\right)$;

$40-50 \%$ platycopids $=4.0-3.5 \mathrm{ml} / 1 \mathrm{O}_{2}\left(\sim 178^{*}-156^{*} \mu \mathrm{mol} / \mathrm{kg}\right)$;

$30-40 \%$ platycopids $=4.5-4.0 \mathrm{ml} / 1 \mathrm{O}_{2}\left(\sim 200^{*}-178^{*} \mu \mathrm{mol} / \mathrm{kg}\right)$;

$20-30 \%$ platycopids $=5.0-4.5 \mathrm{ml} / 1 \mathrm{O}_{2}\left(\sim 223^{*}-200^{*} \mu \mathrm{mol} / \mathrm{kg}\right)$;

$<20 \%$ platycopids $=>5 \mathrm{ml} / 1 \mathrm{O}_{2}(\sim 223 * \mu \mathrm{mol} / \mathrm{kg})$;

* Considering $1.00 \mathrm{ml} / \mathrm{l}=44.66 \mu \mathrm{mol} / \mathrm{kg}$

In the samples studued herein the platycopid abundance varied from $1.9 \%$ to $71.4 \%$ of the total ostracod fauna (Tab. 4, samples 57-2 and 153-8 were excluded since the size of the mesh used in the AGT is larger that $500 \mu \mathrm{m}$ ). Based on measurements from the Woce project (Schlitzer 2000), the $\mathrm{O}_{2}$ concentration in the regions from the three different stations containing Cytherella rwhatleyi sp. nov. varies merely from 210 to $221 \mu \mathrm{mol} /$ $\mathrm{kg}$, instead of varying from $<67$ to $>223 \mu \mathrm{mol} / \mathrm{kg}$, as would be expected by Whatley's scale (2003, see above) (Tab. 4 herein). This new data indicates that probably other factors than $\mathrm{O}_{2}$ concentration influences the ostracod assemblages and that the proposed and widely accepted scale may not be appropriate for paleoreconstructions. This topic will be discussed in more detail in another publication.

TABLE 4. Cytherella rwhatleyi sp. nov. and $\mathrm{O}_{2}$ concentration in the water mass.

Total Ostracoda-total number of ostracod specimens in each sample.

*Wha $-\mathrm{O}_{2}$ concentration as calculated from the percentage of Cytherella rwhatleyi sp. nov using the scale from Whatley and colleagues (2003).

** Data from eWoce (Schlitzer 2000).

\begin{tabular}{|c|c|c|c|c|c|c|c|c|c|c|}
\hline \multirow[t]{2}{*}{ Station } & \multirow[t]{2}{*}{ Gear } & \multirow[t]{2}{*}{$\begin{array}{c}\text { Total } \\
\text { Ostracoda }\end{array}$} & \multirow[t]{2}{*}{$\begin{array}{c}\% \\
\text { Platy }\end{array}$} & \multirow{2}{*}{$\begin{array}{l}\text { Wha* } \\
\text { (?mol/ } \\
\text { Kg) }\end{array}$} & \multirow{2}{*}{$\begin{array}{l}\mathrm{O}^{* * *} \\
(? \mathrm{~mol} / \\
\mathrm{Kg})\end{array}$} & \multirow{2}{*}{$\begin{array}{c}\text { Depth** } \\
\text { (m) }\end{array}$} & \multirow{2}{*}{$\begin{array}{c}\text { Latitude }^{* * *} \\
{ }^{\circ} \mathbf{S}\end{array}$} & \multirow{2}{*}{$\begin{array}{c}\text { Longitude** }^{* *} \\
{ }^{\circ} \mathbf{W}\end{array}$} & \multirow[t]{2}{*}{ e Woce Station** } & \multirow[t]{2}{*}{ Date $^{* *}$} \\
\hline & & & & & & & & & & \\
\hline 89 & EBS & 180 & 16.1 & $>223$ & 215 & 1510 & 72.493 & 22.921 & A23_74JC10_1 12 B & $\begin{array}{l}\text { 01 Apr. } \\
1995\end{array}$ \\
\hline 107 & EBS & 265 & 1.9 & $>223$ & 210 & 1006 & 72.493 & 22.921 & A23_74JC10_1 & $\begin{array}{c}01 \\
\text { Apr.1995 }\end{array}$ \\
\hline $153-4$ & GKG & 7 & 71.4 & $112-89$ & 212 & 2027 & 62.857 & 63.525 & A21_06MT11_5 117 B & $\begin{array}{c}30 \text { Jan. } \\
1990\end{array}$ \\
\hline $153-7$ & EBS & 370 & 41.1 & $178-156$ & 209 & 1962 & 62.6 & 64.272 & A21_06MT11_5 116 B & $\begin{array}{c}29 \text { Jan. } \\
1990\end{array}$ \\
\hline
\end{tabular}




\section{Acknowledgements}

Dr. Dietmar Keyser (ZMH) for his very careful supervision. Dr. Carol Schöning for revising the English. Renate Walter (ZMH) helped with the SEM-photos and computer programs. I also acknowledge Prof. Dr. Angelika Brandt and Dr. Brigitte Ebbe for the coordination of the ANDEEP Project, and the crew and the scientists on board of the R. V. Polarstern during the 4 cruises. Dr. Miranda Lowe (The Natural History Museum, London) is acknowledged for permission of studying the Challenger type material. The revisions from Dr. Kerry Swanson (University of Caterbury) and one anonymous referee greatly improved this publication. Both institutions DAAD (Germany) and CAPES (Brazil) financially supported the author. This is the ANDEEP publication no. 97.

\section{References}

Aiello, G., Barra, D. \& Bonaduce, G (1996) The genus Cytherella Jones, 1849 (Ostracoda) in the Italian TortonianRecent. Revue de Micropaleontologie, 39(3),171-190.

Arntz, E. \& Gutt, J. (1999) The Expedition ANTARKTIS XV/3 (EASIZ II) of RV "Polarstern" in 1998. Berichte zur Polarforschung, 301, 1-229.

Ayress, M.A. (1995) Late Eocene Ostracoda from the Waihao district, South Canterbury, New Zealand. Journal of Paleontology, 69, 897-921.

Bergue, C.T., Costa, K. B., Dwyer, G. \& Moura, C. A. V. (2006) Bathyal ostracode diversity in the Santos Basin, Brazilian Southeast Margin: response to Late Quaternary Climate Changes. Revista Brasileria de Paleontologia, 9(2):201-210.

Bergue, C.T., Coimbra, J.C. \& Cronin, T.M. (2007) Cytherellid species (Ostracoda) and their significance to the Late Quaternary events in the Santos Basin, Brazil. Senckenbergiana maritime, 39(1), 5-12.

Brady, G.S. (1880) Report on the Ostracoda dredged by H.M.S. Challenger during the Years 1873-1876. Report on the Scientific Results of the Voyage of H.M.S. Challenger, Zoology, 1, 1-184.

Brady, G.S. \& Norman, A.M. (1896) A monograph of the marine and fresh-water Ostracoda of the North Atlantic and of Nort-Western Europe. Part II. Sections II-V: Myodocopa, Cladocopa, Platycopa. Scientific Transactions of the Royal Dublin Society, 5, 621-784.

Chapman, F. (1919) Ostracoda. Australasian Antarctic Expedition, 1911-1914, Scientific Reports, Series C., Zoology and Botany, 5, 5-45.

Coles, G.P., Ainsworth, N.R., Whatley, R.C. \& Jones, R.W. (1996) Foraminifera and Ostracoda from Quaternary carbonate mounds associated with gas seepage in the Porcupine Basin, offshore Western Ireland. Revista Española de Micropaleontologia, 28(2), 113-151.

Cronin, T.M. (1983) Bathyal ostracodes from the Florida-Hatteras slope, the Straits of Florida and the Blake Plateau. Marine Micropaleontology, 8(2), 89-119.

De Broyer, C., Guerra-García, J.M., Takeuchi, I., Robert, H., Meerhaeghe, A. (2004) Biodiversity of the Southern Ocean: a catalogue of the Antarctic Caprellidae and Cyamidae (crustacean: Amphipoda) with a distribution and ecological data. Bulletin de l'Institut Royal des Sciences Naturelles de Belgique, Biologie, 74, 61-99.

Dingle, R.V. (1984) Mid-Cretaceous Ostracoda from southern Africa and the Falkland Plateau. Annals of the South African Museum, 93: 97-211.

Dingle, R.V., Lord, A.R. \& Boomer, I.D. (1989) Ostracod faunas and water masses across the continental margin off southwestern Africa. Marine Geology, 87(2-4): 323-328.

Dingle R.V, Lord A.R. \& Boomer I.D. (1990) Deep-water Quaternary Ostracoda from the continental margin off SouthWestern Africa (SE Atlanctic Ocean). Annals of the South African Museum, 99(9), 245-366.

Dingle, R.V. \& Majoran, S. (2001) Palaeo-climatic and -biogeographical implications of Oligocene Ostracoda from CRP-2/2A and CRP-3 drillholes, Victoria Land Basin, Antarctica. Terra Antartica, 8(4), 369-382.

Ducasse, O. \& Peypouquet, J.P. (1979) Cenozoic Ostracodes: their importance for bathymetry, hydrology, and biogeography. In: Montadert, L. \& Roberts, D.G. (Eds.) Initial Reports of the Deep Sea Drilling Project. U.S. Government Printing Office, Washington, pp. 343-363.

Fahrbach, E. (2006) The Expedition ANTARKTIS-XXII/3 (EASIZ II) of RV "Polarstern" in 2005. Berichte zur Polarforschung, 533, 1-246.

Fauth, G., Seeling, J. \& Luther, A. (2003) Campanian (Upper Cretaceous) ostracods from southern James Ross Island, Antarctica. Micropaleontology, 49(1), 95-107.

Guernet, G. (1985) Ostracodes Paleogenes de quelques sites 'D.S.D.P.' de l'Ocean Indien (legs 22 et 23). Revue de Paleo- 
biologie, 4(2), 279-295.

Hartmann,G. (1997) Antarctic and subantarctic Podocopa (Ostracoda). Theses Zoologicae, 26, 1-355.

Hedpeth, J.W. (1969) Distribution of selected groups of marine invertebrates in waters south of $35^{\circ} \mathrm{S}$ latitude. Antarctic Map Folio Series, Folio 11: 1-29.

Horne, D. J., Cohen, A. \& Martens, K. (2002) Taxonomy, morphology and biology of Quaternary and living Ostracoda. In: Holmes, J. A. \& Chivas, A. R. (Eds.), The Ostracoda. Applications in Quaternary Research. American Geophysical Union, Washington D. C., pp. 5-35.

Jarvis, I., Carson, G.A., Cooper, M.K.E., Hart, M.B., Leary, P.N., Tocher, B.A., Horne, D.J. \& Rosenfeld, A. (1988) Microfossil assemblages and the Cenomanian-Turonian (Late Cretaceous) oceanic anoxic event. Cretaceous Research, 9(1), 3-103.

Jellinek, T. \& Swanson, K.M. (2003) Report on the taxonomy, biogeography and phylogeny of mostly living benthic Ostracoda (Crustacea) from deep-sea samples (Intermediate water depths) from the Challenger Plateau (Tasman Sea) and Campbell Plateau (Southern Ocean), New Zealand. Abhandlungen der Senckenbergischen Naturforschenden Gesellschaft, 558, 1-329.

Majoran, S. \& Dingle, R.V. (2001a) Cenozoic deep-sea ostracods from southwestern South Atlantic (DSDP/ODP sites 329, 513 and 699). Revista Española de Micropaleontologia, 33(2), 205-215.

Majoran, S. \& Dingle, R.V. (2001b) Palaeoceanographical changes recorded by Cenozoic deep-sea ostracod assemblages from the South Atlantic and the Southern Ocean (ODP Sites 1087 and 1088). Lethaia, 34, 63-83.

Majoran, S. \& Dingle R.V. (2002) Cenozoic deep-sea ostracods from Maud Rise, Weddell Sea, Antarctica (ODP Site 689): A palaeoceanographical perspective. Geobios, 35(1), 137-152.

Majoran, S., Widmark, J.G.V. \& Kucera, M. (1997) Palaeoecological preferences and geographical distribution of late Maastrichtian deep-sea ostracods in the South Atlantic. Lethaia, 30(1), 53-64.

Mazzini, I. (2005) Taxonomy, biogeography and ecology of Quaternary benthic Ostracoda (Crustacea) from circumpolar deep water of the Emerald Basin (Southern Ocean) and the S Tasman Rise (Tasman Sea). Senckenbergiana maritima, 35(1), 1-119.

Peypouquet, J.P. \& Benson, R.H. (1980) Les ostracodes actuels des bassins du Cap et d'Angola: distribution bathymetrique en fonction de l'hydrologie. Bulletin de l'Institut de Geologie du Bassin d'Aquitaine, 28, 5-12.

Puri, H.S. \& Hulings, N.C. (1976) Designation of lectotypes of some ostracods from the Challenger expedition. Bulletin of the British Museum, 29, 251-315.

Schlitzer, R. (2000) Electronic Atlas of WOCE Hydrographic and Tracer Data Now Available. Eos, Transactions, American Geophysical Union, 81(5), 45. The e Woce atlas is available from http://www.awi-bremerhaven.de/GEO/ eWOCE (accessed 1 July 2007).

Schlitzer, R. (2007) Ocean Data View. Available from: http://odv.awi.de (accessed 4 July 2007).

Schulz, K. (1976) Das Chitinskelett der Podocopida (Ostracoda, Crustacea) und die Frage der Metamerie dieser Gruppe. University of Hamburg, p. 1-167. Unpublished Ph. D. Thesis.

Schornikov, E.I. \& Keyser, D. (2004) The morphology and classification of Paradoxostomatinae (Ostracoda) from the nearshore zone of Madeira and the Canary Islands. Revista Española de Micropaleontologia, 36, 57-81.

Swanson, K. M., Jellinek, T. \& Malz, H. (2005) The platycopine condition: new observations on reproduction, respiration and feeding in living, deep-sea Platycopina (Crustacea, Ostracoda). Senckenbergiana maritime, 35(2), $157-187$.

Tomczak, M. \& Godfrey, J. S. (2002) Regional Oceanography: An Introduction. Version 1.2. Available from http:// www.cmima.csic.es/mirror/mattom/regoc/pdfversion.html.

Tsukagoshi, A., Okada, R. \& Horne D. J. (2006) Appendage homologies and the first record of eyes in platycopid ostracods, with the description of a new species of Keijcyoidea (Crustacea: Ostracoda) from Japan. Hydrobiologia, 559, 255-274.

Whatley, R.C. (1991) The platycopid signal: a means of detecting kenoxic events using Ostracoda. Journal of Micropalaeontology, 10, 181-183.

Whatley, R.C. (1995) Ostracoda and oceanic palaeoxygen levels. Mitteilungen aus dem Hamburgischen Zoologischen Museum und Institut, 92, 337-353.

Whatley, R. C. \& Arias, C. F. (1993) Palaeogene Ostracoda from the Tripoli Basin Libya. Revista Española de Micropaleontologia, 25(2), 125-154.

Whatley, R.C. \& Ayress, M. (1988) Pandemic and endemic distribution patterns in Quaternary deep-sea Ostracoda. Developments in Palaeontology and Stratigraphy, 11, 739-755.

Whatley, R.C. \& Coles, G. (1987) The Late Miocene to Quaternary Ostracoda of Leg 94, Deep Sea Drilling Project. Revista Española de Micropaleontologia, 19, 33-98.

Whatley, R. C. \& Cusminsky, C. (2002) Upper Pliocene Ostracoda from the Burdwood Bank, SW Atlantic. Revista Española de Micropaleontologia, 34(1), 53-80.

Whatley, R.C., Moguilevsky, A., Toy, N., Chadwick, J. \& Feijo Ramos, M.I. (1997) Ostracoda from the South west Atlantic. Part 2. The littoral fauna from between Tierra del Fuego and the Rio de la Plata. Revista Española de Micropaleontologia, 29, 5-83. 
Whatley, R.C., Moguilevsky, A., Chadwick, J., Toy, N. \& Feijo Ramos, M.I. (1998) Ostracoda from the south west Atlantic. Part 3. The Argentinian, Uruguayan and southern Brazilian continental shelf. Revista Española de Micropaleontologia, 30, 89-116.

Whatley, R.C., Staunton, M., Kaesler, R.L. \& Moguilevsky, A. (1996) The taxonomy of Recent Ostracoda from the southern part of the Strait of Magellan. Revista Española de Micropaleontologia, 28, 51-76.

Whatley, R.C., Pyne, R.S. \& Wilkinson, I.P. (2003) Ostracoda and palaeo-oxygen levels, with particular reference to the Upper Cretaceous of East Anglia. Palaeogeography, Palaeoclimatology, Palaeoecology, 194, 355-386. 